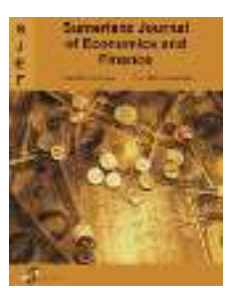

\title{
Identifying and Evaluating the Mechanisms and Modes of Governance of Ecosystem Services - The Case of Bulgarian Agriculture
}

\author{
Hrabrin Bachev \\ Institute of Agricultural Economics, Sofia, Bulgaria \\ Email: hrabrin.bachev@gmail.com
}

Article History

Received: August 23, 2021

Revised: October 10, 2021

Accepted: October 13, 2021

Published: October 16, 2021

\begin{abstract}
This article presents the results of a large-scale study on the mechanisms and modes of governance of diverse ecosystem services in Bulgarian agriculture. Firstly, it identifies the type, amount, and importance of various ecosystem services maintained and "produced" by the Bulgarian farms. The study has found out that country's farms provide a great number of essential ecosystem services among which provisioning food and feed, and conservation of elements of the natural environment prevail. Secondly, it identifies and assesses the efficiency and complementarities of specific modes and mechanisms of governance of ecosystem services used by agricultural holdings. The study had found out that a great variety of private, market, collective, public and hybrid modes of governance of farm activity related to agroecosystem services are applied. There is significant differentiation of employed managerial forms depending on the type of ecosystem services and the specialization of agricultural farms. Furthermore, the management of agroecosystem services is associated with a considerable increase in the production and transaction costs of participating farms as well as big socio-economic and environmental effects for agricultural holdings and other parties. The factors that mostly stimulate the activity of agricultural producers in Bulgaria for protection of (agro)ecosystems services are participation in public support programs, access to farmers' advice, professional training, available information, and innovation, received direct subsidies from EU and national government, personal conviction and satisfaction, positive experience of others, longterm and immediate benefits for the farm, and integration with suppliers, buyers, and processors.

Keywords: Ecosystems; Services; Governance; Efficiency; Agriculture; Farms; Bulgaria.
\end{abstract}

\section{Introduction}

Ecosystem services are widely known as products and other benefits that humans receive from natural ecosystems (MEA, 2005). The agricultural ecosystems and their specific "agro-ecosystem" services are widespread in Bulgaria and internationally (ИAOC; EEA; FAO). Since the introduction of this concept in the last years of the 20th century, (agro) ecosystem services have been intensively promoted, studied, mapped, evaluated, and managed (Adhikari and Boag, 2013; Allen et al., 2011; Boelee, 2013; De Groot et al., 2002; EEA, 2015; FAO, 2016; Fremier et al., 2013; Gao et al., 2018; Garbach et al., 2014; Gemmill-Herren, 2018; Habib et al., 2016; INRA, 2017; Kanianska, 2019; Laurans and Mermet, 2014; Lescourret et al., 2015; Marta-Pedroso et al., 2018; MEA, 2005; Munang et al., 2013; Novikova et al., 2017; Nunes et al., 2014 ; Petteri et al., 2013; Power, 2010; Scholes et al., 2013; Tsiafouli et al., 2017; Van Oudenhoven, 2020; Wang et al., 2013; Wood et al., 2015; Zhan, 2015).

Despite growing environmental issues, and increasing public and private interests, the scientific studies in that new area are still a "work in progress". Research is commonly limited to a certain type of agro-ecosystem services (e.g. plant pollination, biodiversity conservation, etc.), a particular ecosystem (e.g. Zapadna Stara Planina, etc.), a single aspect of the management (agronomic, technological, etc.), a specific form of governance (a public support scheme, organic agriculture, etc.), a separate level of management (farming organization, region, etc.), the specific type of costs and benefits (production, direct, etc.), etc. At the same time, the importance of effective management ("good" governance) for conservation and sustainable provision of ecosystem services in general and of a certain type has been broadly recognized by the academic community, policymakers, interest groups, professional and business organizations, and the public at large (Bachev, 2009; EEA, 2015; UN, 2005).

In Bulgaria, research on economic and other issues related to agroecosystem services are at the beginning stage and mostly at "conceptual and methodological" level (Bachev, 2010; Grigorova and Kazakova, 2008; Todorova, 2017; ИАОС, 2020; Казакова, 2016; Недков, 2016; Николов, 2018; Тодорова, 2017; Чипев et al., 2017). Besides, there very few studies on dominating modes of governance at the current stage of development and fundamental transformation of EU CAP (Башев, 2012;2020). This article fills the gap and presents the result of the first-in-kind "large-scale" study on governance mechanisms and modes of ecosystem services in Bulgarian agriculture. 


\section{Methods and Data}

„Agrarian“ecosystems and ,agrarian“" ecosystem services are those associated with the agricultural ,production“ (Bachev, 2020a). The hierarchical system of agroecosystems includes multiple levels (from individual farm plot/section, area, micro-region, macro-region, etc.) while their (ecosystem) services are classified into different categories (provisional, economic, recreational, aesthetic, cultural, educational, supporting, biodiversity conservation, water purification and retention, flood and fire protection, climate regulation, etc) (MEA).

Indivial farm is the main organizational unit in agriculture that manages resources, technologies and activities and produces a variety of products, including the positive and negative services of agro-ecosystems (Bachev, 2009;2020а; Башев, 2020). The governance of agro-ecosystem services is an integral part of the management of agricultural farm, and the farm - the first (lowest) level for agro-ecosystem services management ${ }^{l}$. The term "management of (agro)ecosystem services" refers to the management of human actions and behavior related to preservation, improving and recovery of ecosystems and ecosystem services (Bachev, 2009). The system of governance of agro-ecosystem services always includes the farm as a key element (first level) of management of agro-ecosystems and their services (Figure 1). Other agrarian and not agrarian agents (resource owners, inputs suppliers, wholesale buyers and processors, interests groups, policymakers, local and national authorities, residence and visitors of rural areas, final consumers, international organizations, etc.) also take part in the management of agroecosystem services at farms, regional, sectoral, national and international levels (Bachev, 2020a).

Farmers use diverse mechanisms and modes to manage their activity and relations with other agents (Bachev, 2010; Williamson, 1996): internal - direct production management, own conviction of farm manager/owner, building reputation, etc.; market - free-market price movements, competition, etc.; contract - special or interlinked contracts, etc.; collective - cooperation, joint initiatives, etc.; public - public eco-contract, cross-compliance against EU subsidization, etc. Detailed presentation of the New Institutional Economics framework for studying and evaluating generic modes of governance, and comparative advantages and disadvantages of individual forms used for ecosystem services management in Bulgarian agriculture is done in other publications (Bachev, 2009;2011;2012;2020b).

Figure-1. Levels and Modes of Governance of Agroecosystem Services

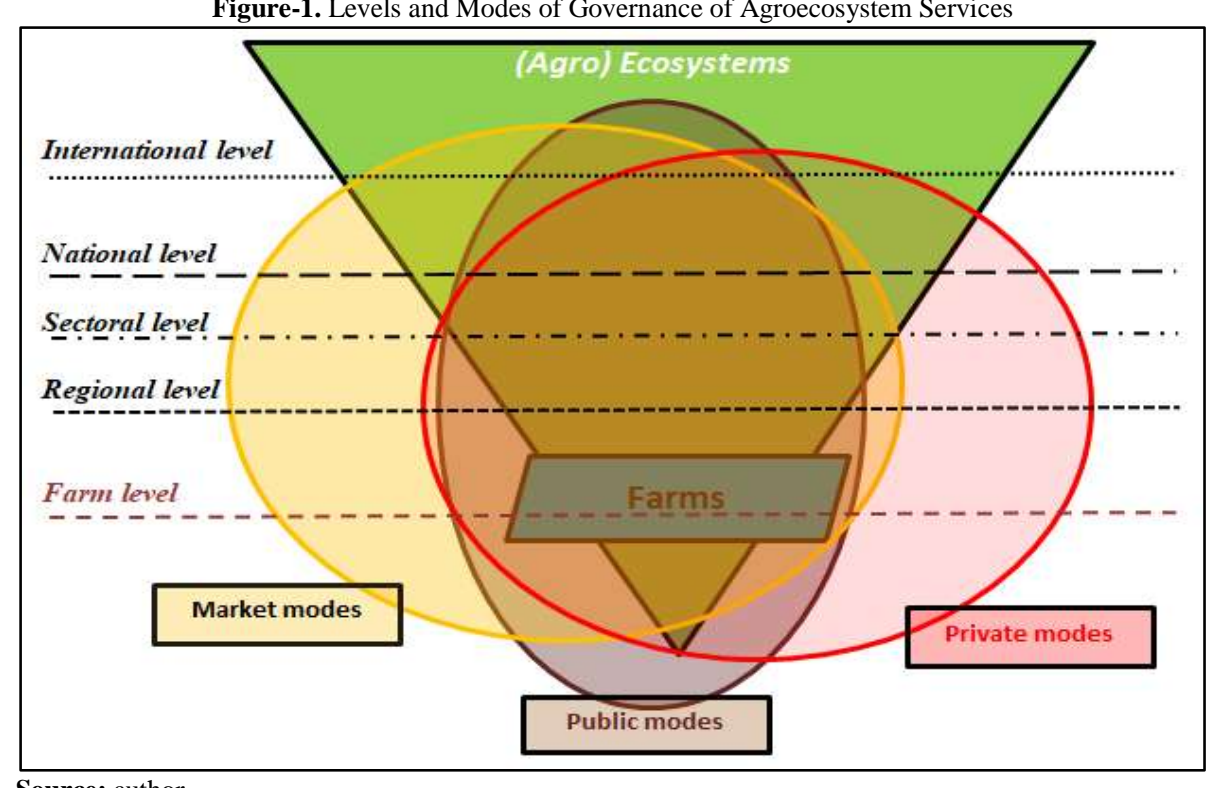

Source: author

In Bulgaria there is no available statisctical and other data on services provided by different type of agroecosystems. Since the individual farm is the basic unit of management of agrarian activities and provision of agro-ecostsem services, our study has focused on the (individual) farm level of maintainance and supply of ecosystem services. The agroecosystem services at a higher lever are evaluated as sum of agroecosystem services provided by the farms associated with the relevant (agro)ecosystems. Concequently, there is an unavoidable error from double accouning and/or uncalculated trade offs, sinergies, complementarities and contervercies of analised agroecosystem services of different type.

This study aims to identify modes, efficiency and factors of agroecosystem services management at the farm level in Bulgaria. In the country, there are statistical and other data for the type of agroecosystem service provided by farms and the specific forms of management applied by agricultural holdings. Therefore, a literature review and widespread practices examination has been made to prepare the list of diverse types of agro-ecosystem services maintained or provided as well as major forms of management used by the farms. A survey with the managers of 324 "typical" farms ${ }^{2}$ of different legal type, size, production specialization, and ecological and geographical location was conducted in October 2020 to identify the structure of ecosystem services "produced" and governing modes

\footnotetext{
${ }^{1}$ Farm borders rarely coincide with the (agro) ecosystem boundaries (Bachev)

${ }^{2}$ The author is grateful to all managers of the surveyed farms for the information provided, and to the NAAS and the cooperating producers' organizations for the assistance.
} 
employed. The questionnaire also gives an option to respondants to add specific services provided and managerial forms practiced.

Surveyed farms account for almost $0,5 \%$ of all registered agricultural producers in the country. The structure of studied holdings aproximately correspond to the real structure of farms in Bulgaria. The classification of agricultural holdings has been done according to official classification in the country and EU. The subsectors, regional, national, etc. summaries are arithmetic averages of data provided by the individual farms belonging to respective agrosystems.

The accessments of the farm manageres about type, ammount, and importance of agroecosystem services they maintain or prodice give good insights on the state and efficiency of agrpecosystem services in the country. The assimetry of information is quite big in the area and farmers are among the most informed actors about agricultural efforts and contribution toward (agro)ecosystem services. However, the managers estimates also reflects the "personal" (subjecive) knowlege and perceptions of the farmers on agroecosystem services, and their values, the efforts rather than output and impacts, etc. The objectivity of the study would enhanced during the next stage of the study when farms representations will be increased and their assessments complemented ("corrected") with estimates of stakeholders, consumers, experts, etc.

\section{Type and Amount of Farms' Ecosystem Services}

The conducted survey allowed to make a detailed map of the agro-ecosystem services of different types provided by agricultural producers, as well as to determine the structure and volume of the services of the agroecosystems of various types. The share of farms involved in activities related to the provision of agro-ecosystem service of a certain kind gives a good idea of the volume of "produced" service of that type. The majority of Bulgarian farms participate in the "Production of products (fruits, vegetables, flowers, etc.) for direct human consumption" (59.3\%), which is one of the main "services" of agro-ecosystems in the country (Figure 2). A significant part of the farms also "Produce raw materials (fruits, milk, etc.) for the food industry" (15.4\%). Other "production" services in which a smaller part of the farms participate are "Production of animal feed" (8.6\%), "Own processing of agricultural products" (6.17\%), "Production of seeds, saplings, animals, etc. for farms" (4.3\%) and "Production of raw materials for cosmetic, textile, energy, etc. industry" (3.09\%). Other "production" services of agroecosystems, in which a relatively small part of agricultural producers participate, are "Provision of services to other farms and agricultural organizations" (2.47\%), "Provision of services to end users (riding, fruit picking, etc.)" $(1.85 \%)$, "Provision of tourist and restaurant services" (0.62\%) and "Production of bio, wind, solar, etc. energy" $(0.62 \%)$. Other important services of the agro-ecosystems, in which "supply" a large part of the agricultural holdings participate, are "Hiring workers" (11.11\%) and "Providing free access on the farm to outsiders" $(10.49 \%)$.

Relatively many of the farms are also involved in the protection and preservation of technological, biological, cultural and other heritage - "Preservation of traditional crops and plant varieties" (6.17\%), "Preservation of traditional species and breeds of animals" (7.41\%), "Preservation of traditional methods, technologies and crafts" $(6.17 \%)$, "Preservation of traditional products" (6.17\%), "Preservation of traditional services" (5.55\%), "Preservation of traditions and customs" (3.7\%) and "Preservation of historical heritage" (1.23\%). A major part of agro-ecosystem services consists in preserving, restoring and improving the elements of the natural environment - soil, water, air, gene pool, landscape, plants and animals, etc. The activity of a large part of the agricultural holdings is aimed at the production of this type of agro-ecosystem services - "Disease control (measures)" (24.69\%), "Pest control (measures)" (19.75\%), "Protection of natural biodiversity" (18.52\%), "Protection and improvement of soil fertility" (16.67\%), "Protection from soil erosion" (13.58\%), "Protection and improvement of soil purity" (12.34\%), "Protection of surface water" (11.73\%), "Protection of groundwater purity” (9.88\%), "Ffire protection (measures)" $(8.64 \%)$, and "Protection of plant and/or animal gene pool" $(8.02 \%)$.

A relatively smaller part of the farms are also included in "(Measures for) water conservation and saving" (5.55\%), "(Measures for) regulation of the correct outflow of water" (4.32\%), "Preservation of air quility" (4.32\%), "Preservation of traditional scinery and landscape" (3.7\%), "Improvement (aesthetics, aroma, land use, etc.) of scinery and landscape "(3.09\%), "(Measures for) regulation and improvement of the microclimate" (3.09\%), "Flood protection (measures)" (2.47\%), and "Greenhouse gas emission reduction (measures)" (2.47\%), and "(Measures) for storm protection" (1.85\%). One of the essential services of agroecosystems is the recovery and recycling of "waste" from various activities in the sector and other industries. The main activity of many farms in this regard is "Use of manure on the farm" (13.58\%), and to a lesser extent "Reuse and recycling of waste, composting, etc." (3.09\%) and "Use of sludge from water treatment on-farm" $(0.62 \%)$.

Agri-ecosystems also make a significant contribution to training farmers and non-agricultural agents, conducting scientific experiments, demonstrating innovation, and so on. In such educational, scientific and innovative services participate a smaller part of the agricultural producers - "Training and advice of other farmers" (4.32\%), "Training of students, consumers, etc." (1.85\%), "Demonstration of production, technologies, innovations, etc." (1.85\%) and "Conducting a scientific experiment" $(1.85 \%)$. Agroecosystems also contribute to the "Protection and improvement of non-agricultural (forest, lake, urban, etc.) ecosystems" with $4.32 \%$ of farms in the country engaged in such efforts.

The extent of participation of supplying farms in the presevation or production of agro-ecosystem services is not equal. For most agri-ecosystem services, the holdings involved in the activities do so "To a large extent' (Figure 2). Therefore, "permanent" investments in agri-ecosystem services and "specialization" in the provision of agroecosystem services of a certain type to participating farms can be considered. In some agro-ecosystem services, the share of farms involved to a large and small extent is equal - for example in the use of manure on the farm, the provision of services to other farms and agricultural organizations, (flood protection) measures, and the hiring of 


\section{Sumerianz Journal of Economics and Finance}

workers. Therefore, a significant proportion of farms are either in the process of initially "entering" (testing, studying, adapting, etc.) in the related agro-ecosystem services, or participate in this supply as ancillary or related to the main activity. With regard to three main types of agro-subsistence services, most of the farms involved in their supply do so to a small extent - on farm using sludge from water treatment, training of students, consumers, etc., and use and recycling of waste, composting, etc. This is a sign of either the initial entry into or exit from this activity, or the inefficiency of its further expansion (intensification) by practicing farms.

There are also significant differences and deviations from the average level in the participation of agricultural holdings of variouse types in the preservation and supply of agro-ecosystem services in the main geographical, ecological and agricultural regions of the country (Bachev, 2021). The unequal participation of farmers in the provision of agro-ecosystem services of different types and unlike degrees of involvement in such activities shows the need to take measures to improve, diversify and intensify this activity through training, information, exchange of experience, public incentives, etc.

Figure-2. Share of farms participating and providing to a big extent diverse ecosystem services in Bulgaria (percentages)

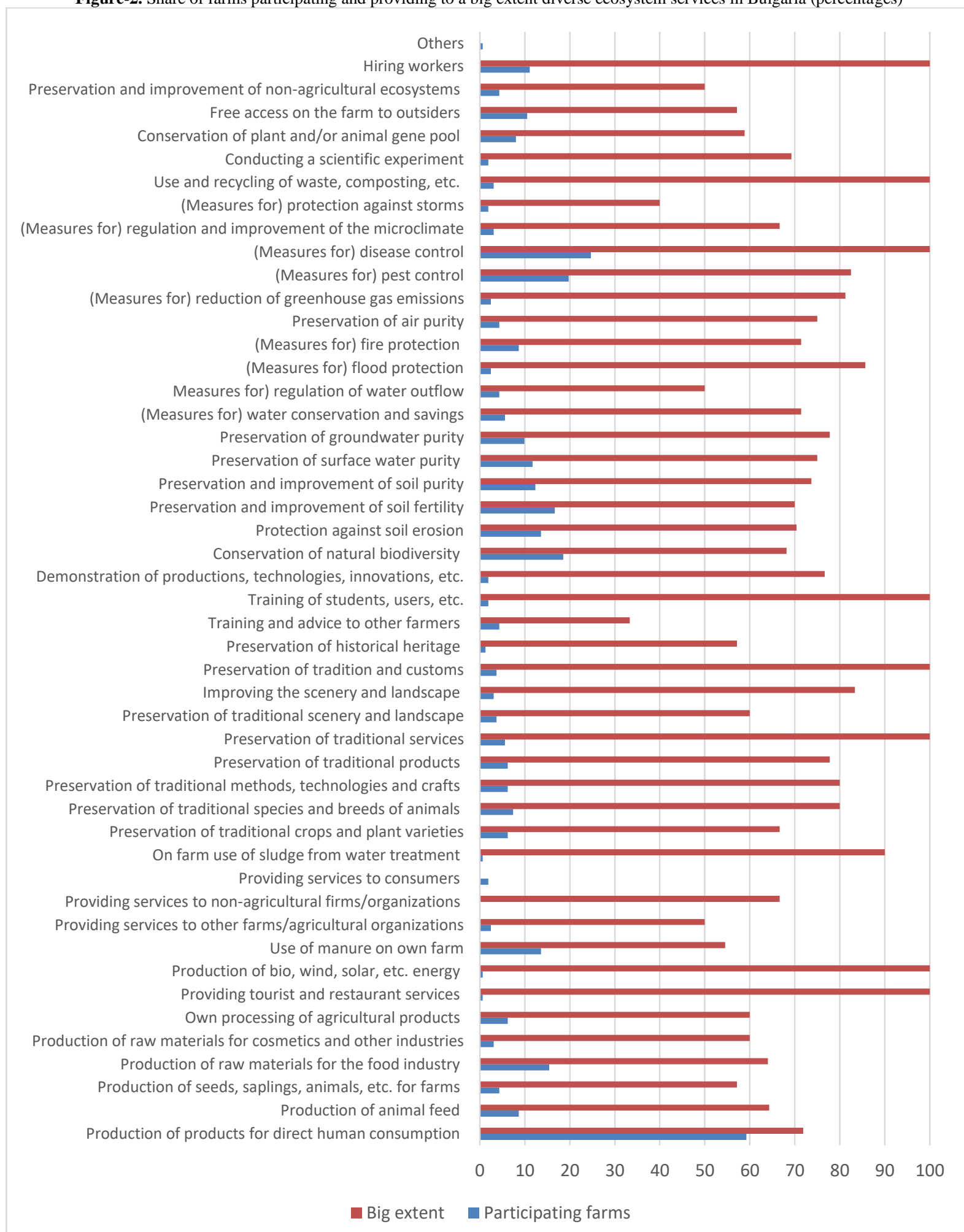

Source: Survey of agricultural producers, 2020 


\section{Dominating Mechanisms of Management of Farms' Ecosystem Services}

The survey found that a large proportion of Bulgarian farms use some specific mechanisms in making decisions about managing their activities related to agroecosystem services (Figure 3). However, a different proportion of farms apply specific mechanisms to manage the various aspects of the activity related to the provision of agroecosystem services. In the Production of products for direct consumption, all farms use some "special" forms ${ }^{3}$. A relatively large part of the farms also uses specific mechanisms in the management of Soil Protection (31.48\%), Water Protection (33.95\%), Biodiversity Protection (32.72\%) and Landscape and Scenery Protection (20.37\%). Fewer farms use specific forms to manage the supply of the other main types of agro-ecosystem services.

Figure-3. Share of farms using specific mechanisms for decision-making of activity associated with agroecosystem services in Bulgaria (percentages)

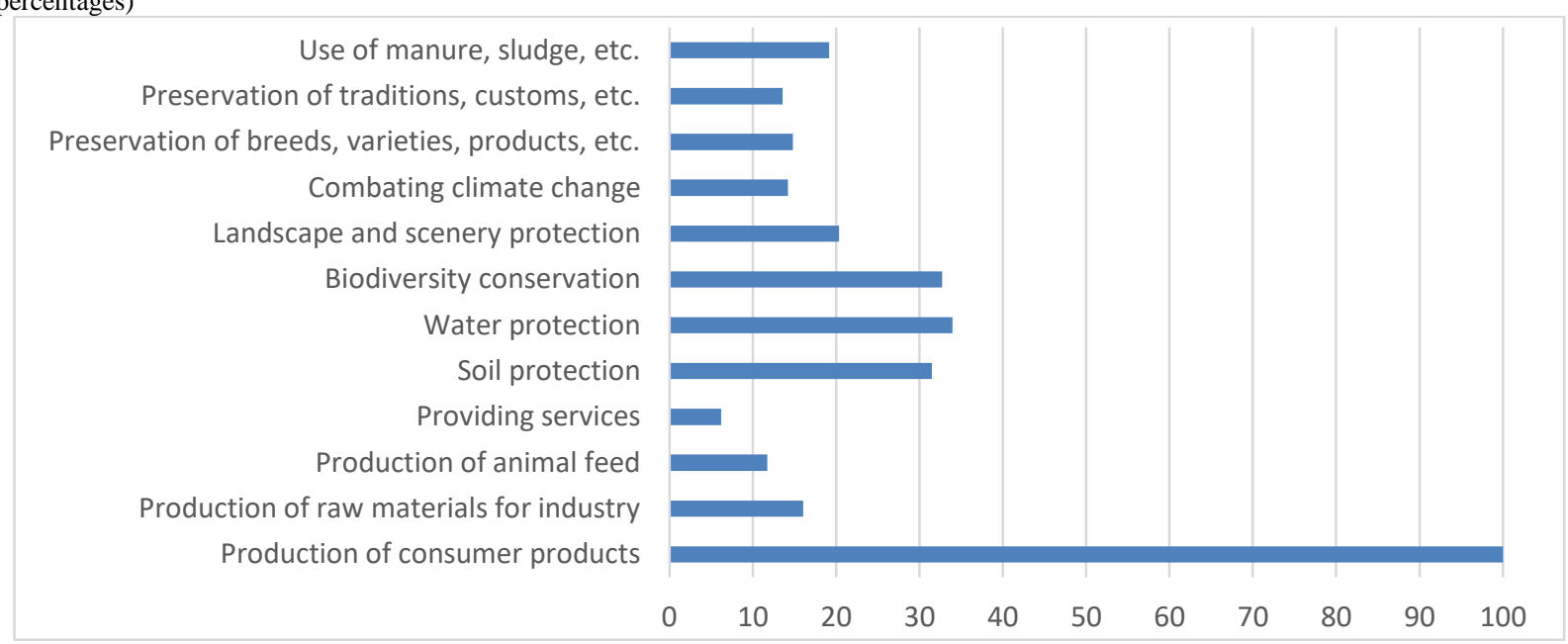

Source: Survey of agricultural producers, 2020

The specific forms and mechanisms applied for the effective governance of different types of agro-ecosystem services are quite different. For most farms, independent internal (Independently by the farm) management is essential for the supply of all major agroecosystem services (Figure 4). This form is practiced by the vast majority of farms, in agro-ecosystem services with the character of "local or public goods" (inability to sell and protect rights, high specificity and uncertainty, low frequency of exchange with a particular user, etc.) - Soil protection (90.2\%), Water protection $(80 \%)$, Biodiversity protection $(81.13 \%)$, Landscape and scenery protection $(81.82 \%)$, Climate change control (78.26\%), Preservation of breeds, varieties, products, etc. (87.5\%) and Use of manure, sludge, etc. $(90.32 \%)$. This form is least used in making management decisions concerning the production of raw materials for industry $(42.31 \%)$, where there is a high dependency (specificity of the product, capacity, delivery time, location, etc.) of the particular buyer(s) and market(s) and there is a need to use more effective forms of coordination and governance.

Figure-4. Mechanisms used in decision-making on farm activities related to different types of agro-ecosystem services in Bulgaria

Use of manure, sludge, etc Preservation of traditions, customs, etc. Preservation of breeds, varieties, products, etc.

Combating climate change

Landscape and scenery protection

Biodiversity conservation

Water protection

Soil protection

Providing services

Production of animal feed

Production of raw materials for industry

Production of consumer products

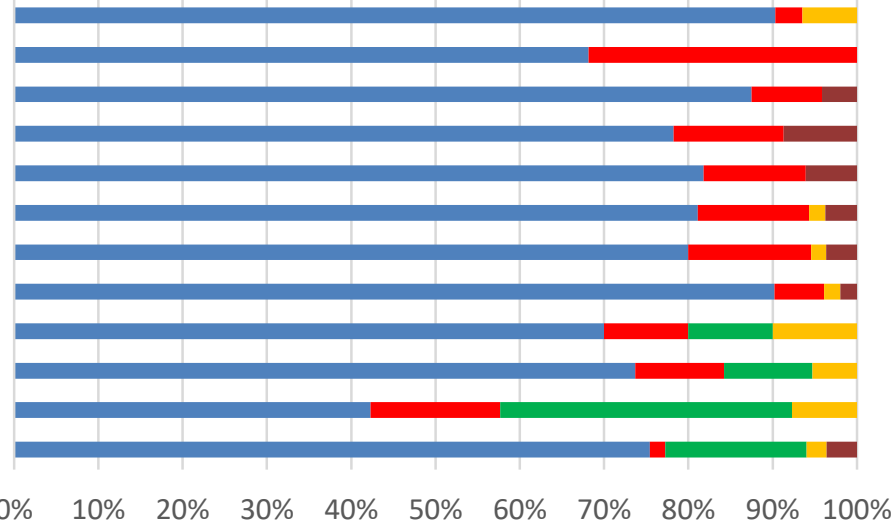

- Independently in your farm

- Collectively with other farms and agents

- Market prices and demand

Contract with private agent(s)

- Participation in a public program

Source: Survey of agricultural producers, 2020

\footnotetext{
${ }^{3}$ The modes and efficiency of governance of this type of activity of Bulgarian farms have been widely studied and presented in academic literature Bachev,(2010), Bachev,(2018) .
} 
Collective decision-making with other farmers and agents is a form that is applied by a significant part of the farms in relation to the Preservation of traditions, customs, etc. (31.82\%) and a large part of them in the Production of raw materials for industry (15.38\%), Water protection (14.5\%), Biodiversity protection (13.21\%), Landscape and Scenery protection $(12.12 \%)$ and Combating climate change (13.04\%). The collective form for most of these services (with the character of "local or public goods") is determined by the need for coordinated "collective action" (high dependence of assets and actions) to achieve a certain positive result. The collective organization in the production of raw materials for the industry is most often required by the need for a certain minimum volume and standardization for efficient market or vertically integrated trade (achieving efficiency in wholesale trade, compliance with the requirements of processors for quality, volume and frequency of supplies, etc.) or to oppose an existing (quasi)monopoly, etc.

Market mechanism and market prices and demand are exclusively and widely applied only to traditional (commercial) farming products and services - mostly in the Production of raw materials for industry (34.62\%), Production of products for direct consumption (16.77\%), and in less extent in Production of animal feed $(10.53 \%)$ and Provision of services (10\%). As mass and standard products are traded, the market works well and there is no need to use a more expensive special form to govern the relationship between supplier and buyer.

A special private form - Contract with a private agent/s is used when it is necessary to regulate in detail the relations of the parties due to high unilateral or bilateral dependency of assets, high frequency of transactions between the same agents, and uncertainty and risk of market trading (specification of the product, delivery time, a form of payment, interlinked transactions, a guarantee of trade between the parties, etc.). The contractual form is applied by every tenth farm in the provision of services, and a large part of the farms in the production of raw materials for industry (7.69\%), production of animal feed (5.26\%), and the use of manure, sludge, etc. (6.45\%).

Public intervention (support) is required when private and market forms cannot fully govern the supply of certain agro-ecosystem services due to public nature, low appropriability, high specificity and uncertainty, etc. Participation in a public program is a form that is applied most by farms in the Fight against climate change $(8.69 \%)$, Landscape and scenery protection $(6.06 \%)$, and Preservation of breeds, varieties, products, etc. $(4.17 \%)$.

Depending on the specificity of production (and the production agro-ecosystem), farms with different specializations use to unlike extent specific mechanisms for deciding on the activity related to agroecosystem services of different types (Figure 5). The largest share of farms specialized in Field crops (28.57\%) use specific mechanisms in the production of raw materials for industry. The most widespread special mechanisms for the production of animal feed are practiced at Mixed crop-livestock holdings (40.74\%). Every third producer in Pigs, Poultry and Rabbits applies similar mechanisms for (standard) services provision. A significant part of the specialized in Permanent crops $(43.86 \%)$ and Mix crops $(36.36 \%)$ need special management mechanisms for soil Protection. In water protection, most of the holdings in Permanent crops (40.35\%), Mix crop-livestock (37.04\%) and Mix crops (36.36\%) adapt special forms. Farms in Permanent crops (38.60\%), Mixed Livestock (38.46\%), and Mixed crop-livestock (37.04\%) use the most specific mechanisms for biodiversity conservation. One-third of the specialized holdings in Pigs, Poultry and Rabbits apply special forms for landscape and scenery protection. The largest part of the farms with Mix crops (27.27\%) and Grazing livestock (18.18\%) apply special management mechanisms in the fight against climate change. For the preservation of breeds, varieties, products, etc. and for the preservation of traditions, customs, etc. every third farm with pigs, poultry and rabbits needs such mechanisms. The majority of those specialized in Pigs, Poultry and Rabbits (66.67\%) and Mixed crops (63.64\%) apply special mechanisms in making management decisions for the use of manure, sludge, etc.

At the same time, however, there is a significant variation in the type of specific mechanisms used to make management decisions by farms with different specializations. For example, for the Conservation of Natural Biodiversity, every third farm specializing in field crops applies Participation in a public program. When managing the supply of the same ecosystem service, two-thirds of the farms with bee colonies and one-third of those in Mixed crops do it Collectively with other farms and agents. Similarly, when managing the fight against climate change, half of the Mixed Crop-Livestock holdings do so Collectively with other farmers and agents, while one-fifth of the farms specializing in Permanent crops use Participation in a public program.

For some agroecosystem services with a high (capacity, location, product, etc.) specificity to a particular buyer(s) no (free)market forms (Soils protection, Waters protection, Protection of biodiversity, Preservation of landscape and scenery, Combating climate change, Preservation of breeds, varieties, products, etc.) or public forms (Production of raw materials for industry, Production of animal feed, and Services supply), or both market and trilateral with public involvment forms (Preservation of traditions, customs, etc., and Use of manure, sludge, etc.) develop. For the later mostly or exclusively private (internal, contract, collective, etc.) modes are used by all types of farms to govern their activity and relations associated with ecosystem services.

Our study has found no significant differences found in specific modes of management of specific agroecosystem services applied by farms of different juridical types (Sole Trader, Cooperative, etc.), in different ecosystems (mountainous, plain, etc.) and regions of the country. Thus differentiation of the managerial modes mostly depends on the specificity of the agroecosystem services and the subsector of agricultural production. 
Figure-5. Share of farms with different specialization, using specific mechanisms in decision-making on the activity related to agroecosystem services in Bulgaria (percentages)

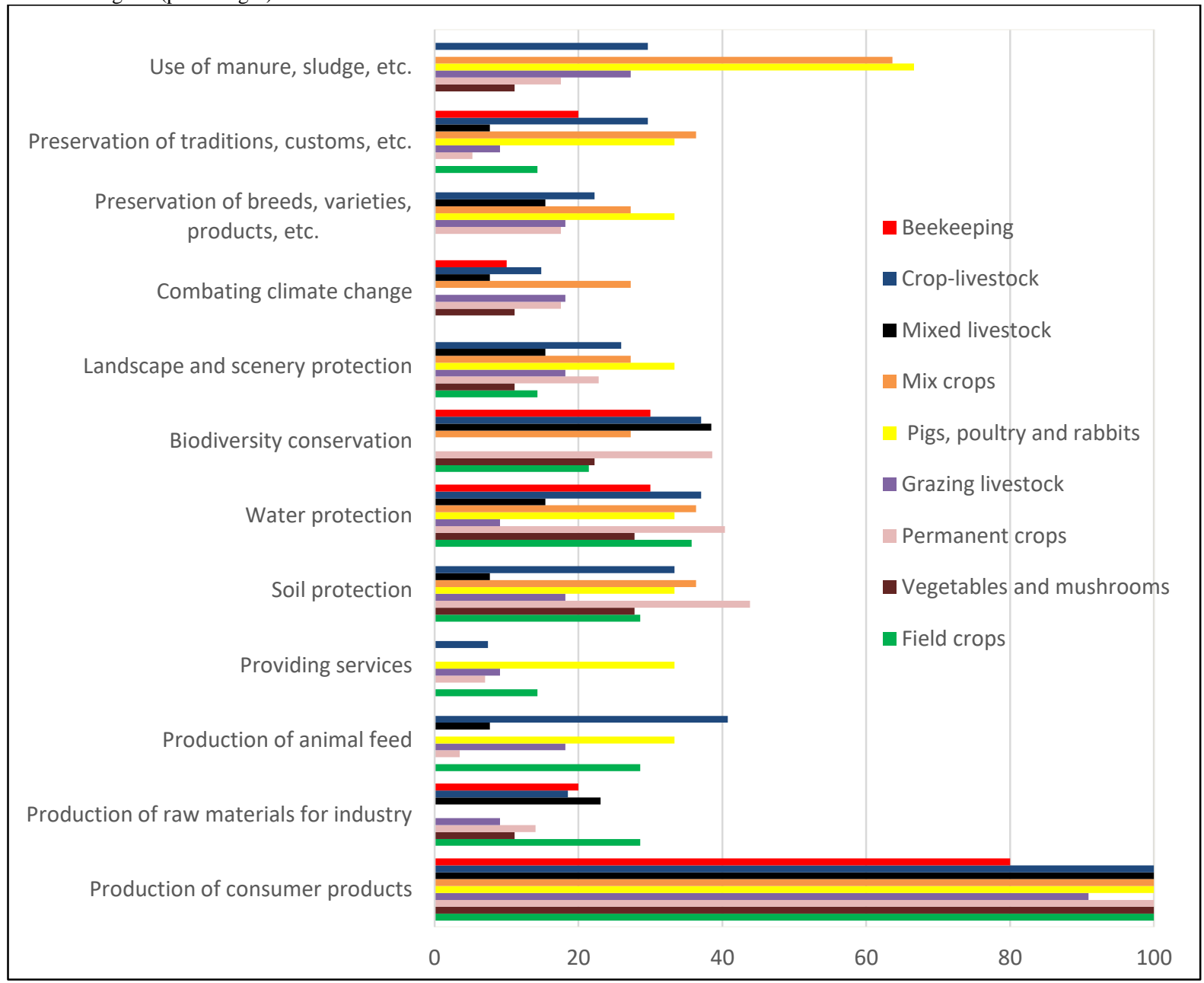

Source: Survey of agricultural producers, 2020

\section{Private, Collective and Market Modes}

Most of the surveyed farms apply special private and market forms to govern the supply of agro-ecosystem services. Over $17 \%$ of all farms $(17.28 \%)$ are certified for organic production, and a small part combines mixed organic and traditional production (3.09\%) (Figure 6). Formal certification is associated with additional costs for farmers (conversion period, certification, current control, etc.) and consumers (premium to market price), but also brings significant benefits for both parties. Farmers have a formal guarantee for the authenticity of their products, receive a price bonus and public subsidies, develop a reputation and market position for special and high-quality products. Consumers receive a guarantee of authenticity and low-cost acquisition of products related to agriecosystem services. The process is controlled by an independent (third) party, which increases trust and reduces transaction costs. This threelateral market-oriented form will become even more important in the future given the growing consumer demand in the country and on international markets, and the further greening of the CAP in the next programming period and increasing incentives to expand organic production in the EU. 
Figure-6. Share of farms applying diverse private, collective, and market forms for the supply of agro-ecosystem services in Bulgaria (percentages)

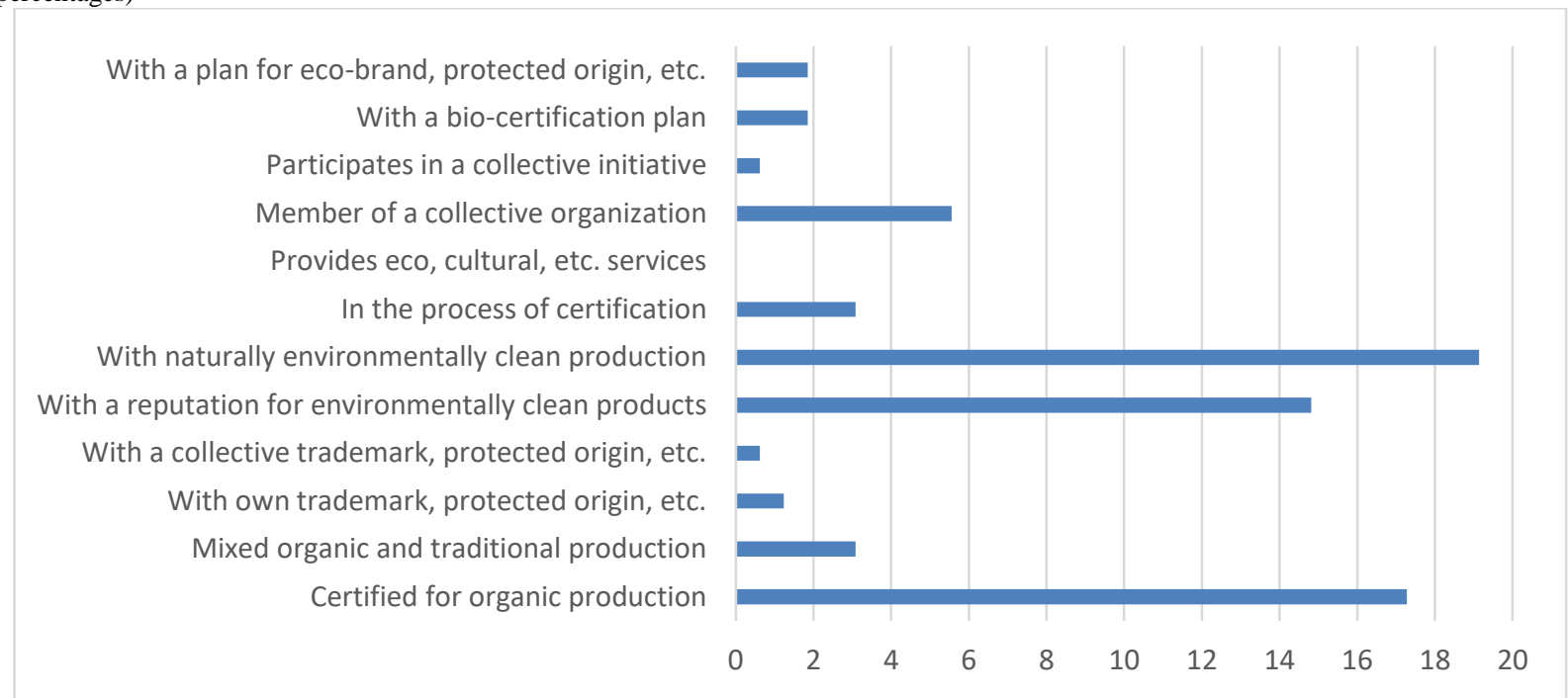

Source: Survey of agricultural producers, 2020

Most of the agricultural holdings have a built Reputation for ecologically clean products (14.81\%) or With naturally ecologically clean production (19.14\%). Informal private and collective forms such as building a "good reputation" for special quality, products, origins, etc., of certain farms, ecosystems and entire regions are widespread in the country's agricultural practice. In the future, they will continue to effectively manage the relationship between producers and consumers for the supply of agri-ecosystem services. Transaction costs are low, as long-term "personal" relationships ("clientalization", high frequency) are developed for trading certain products, primarily in local and regional markets, and opportunism is punished by the cessation of trade and "bad" reputation.

Due to high costs (registrations, control, etc.) and low returns, very few farms apply other formal private or collective forms of agri-ecosystem services management. A little over $5 \%$ are members of a collective organization $(5.56 \%)$, a little over $1 \%$ are With own trademark, protected origin, etc. $(1.23 \%)$, less than $1 \%$ participate in a Collective Trademark, Protected Origin, etc. $(0.62 \%)$ or in a Collective Initiative $(0.62 \%)$. However, given the significant transactional benefits (sales to large retail chains, exports, premiums, etc.), the number of farms investing in such special private and market forms is gradually increasing. In the process of certification are $3.01 \%$ of all farms are, With a plan for bio-certification $1.8 \%$ and With a plan for eco-brand, protected origin, etc. $1.85 \%$.

Nearly three-quarters of the surveyed farms reported that they participate in some initiative for the protection of ecosystems and ecosystem services. The majority of farms Implement own (private) initiative in this regard $(56.56 \%)$ (Figure 7). Quite a part of the holdings Implements informal Initiatives of other farms (13.11\%). Almost every tenth $(9.84 \%)$ reports participating in a State initiative related to the protection of ecosystems and ecosystem services. This hybrid (public-private, trilateral) form is also usually associated with receiving certain subsidies or other support in return for certain commitments for improved environmental management. Just over $2 \%$ of farms Have a contract with the state to implement such an initiative (2.46\%). A small share of farms participates in other private and collective formal environmental management initiatives - Formal initiatives of other farms (2.46\%), Initiative of a professional organization (4.1\%), Initiative of a non-governmental organization (3.28\%), Initiative of a cooperative of which they are members $(2.46 \%)$, and International initiative $(0.82 \%)$.For a small part of the farms, the initiative is of (induced by) Supplier of the farm $(1.64 \%)$ or by Buyer $(0.82 \%)$, and $1.64 \%$ of the farms even Have a contract with a private organization for implementation of eco-initiative.

All this shows that the effective forms that farms and other stakeholders use to govern their relationships and actions related to environmental protection and agri-ecosystem services are diversifying. 
Sumerianz Journal of Economics and Finance

Figure-7. Share of farms participating in an initiative for the protection of ecosystems and ecosystem services in Bulgaria (percentages)

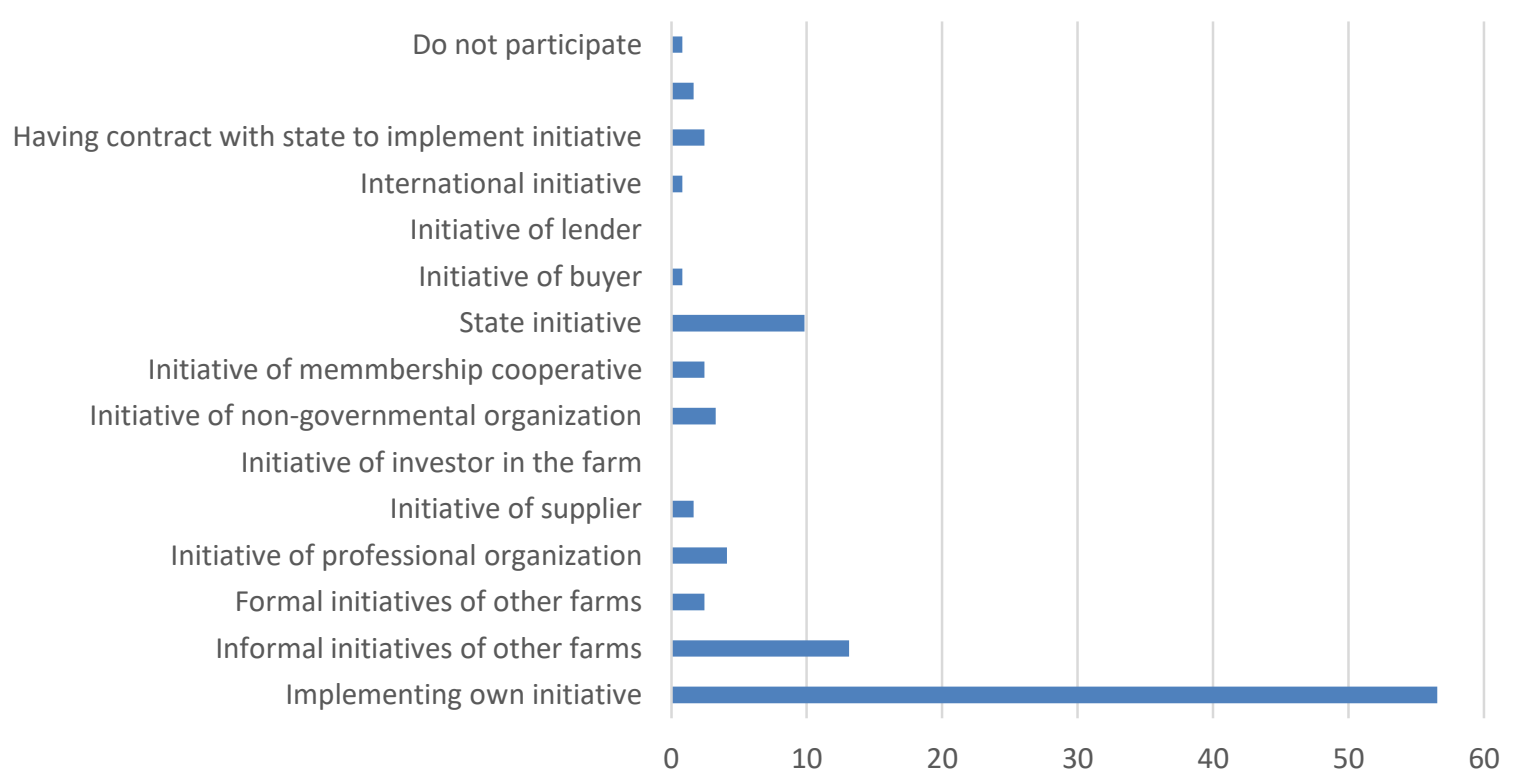

Source: Survey of agricultural producers, 2020

\section{Providing Outside Access to the Territory of the Farm}

Providing external access to the territory of agricultural holdings is a basic form of supply and/or consumption of ecosystem services in agriculture. The share of farms that provide access to outsiders on their territory varies depending on the agroecosystem services used (Figure 8). A significant part of the farms allows External visits to the farm $(37.65 \%)$ and Collection of information from individuals and institutions $(32.72 \%)$. Relatively smaller is the number of farms that allow Passage through the farm (12.35\%). Every tenth farm allows Grazing of animals of other individuals and farms (10.49\%) and Collection of unnecessary for the farm harvest, including residues (10.49\%). Quite a few of the Bulgarian farms also provide their territory for Scientific experiments and demonstrations $(8.64 \%)$, Tourism $(6.17 \%)$ and Collection of wild plants and animals $(5.55 \%)$. To the least extent, the territory of the farms is available for the Organization of private events (entertainment, etc.) (4.32\%), Hunting and fishing (3.09\%) and Organization of public events $(2.47 \%)$. An insignificant part of the holdings also indicated Other reasons such as Veterinary services $(1.23 \%)$ and Control bodies and experts $(0.62 \%)$.

Figure-8. Share of farms that provide external access to their territory for using of various ecosystem services in Bulgaria (percentages)

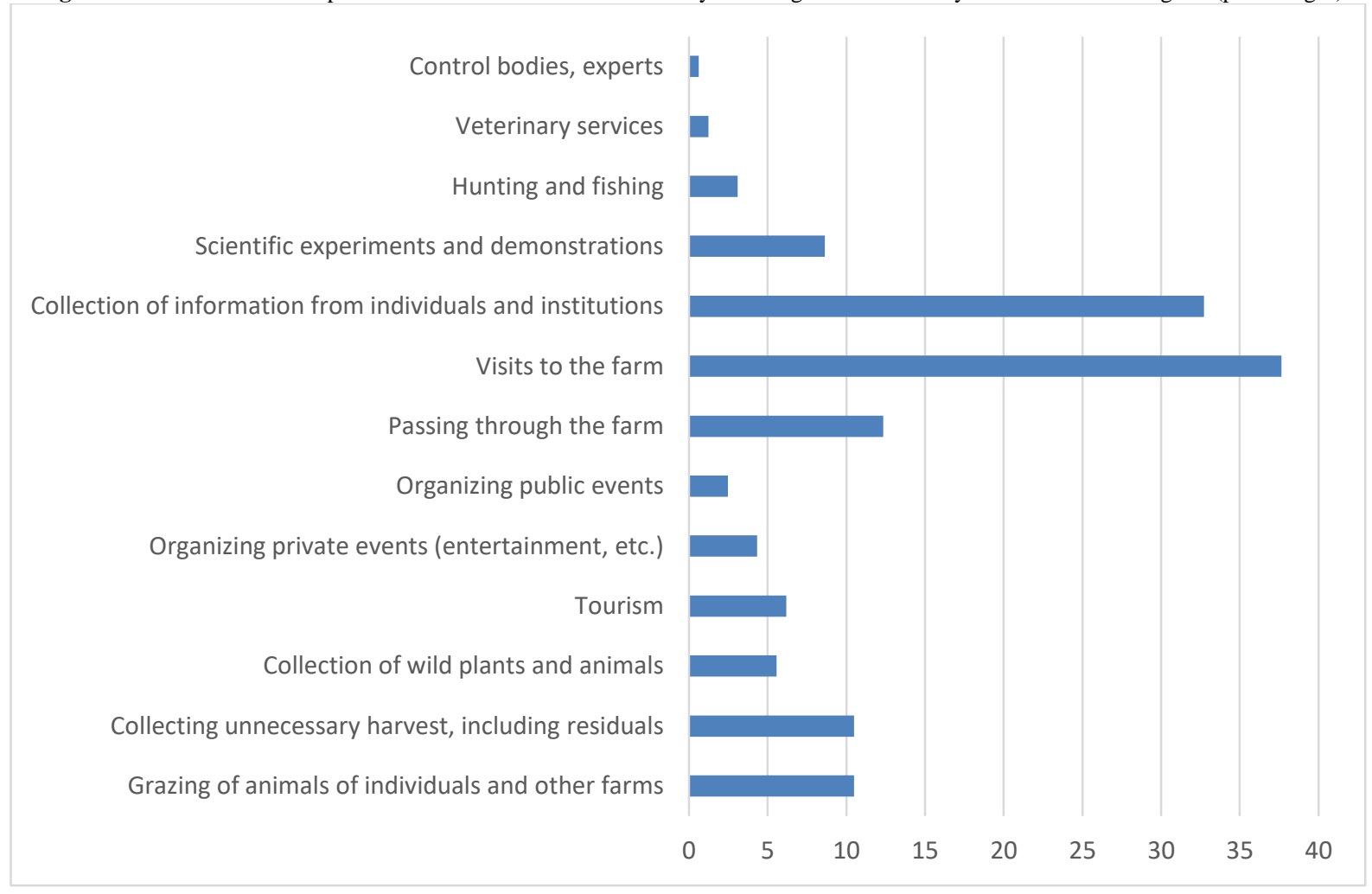

Source: Survey of agricultural producers, 2020

For the different types of external access on the territory of the farms, specific forms for governing the relationship of agents are practiced (Figure 9). Free and unrestricted access is the dominant form of providing access 
to the territory of the farm for grazing animals of individuals and other farms $(47.06 \%)$, Collection of wild plants and animals (66.67\%), Tourism (70\%), Organizing private events $(42.86 \%)$, Organization of public events $(50 \%)$, Passage through the farm (65\%), Veterinary services (50\%) and Control bodies and experts (100\%). This form is also practiced by a large number of farms for the Collection of unnecessary harvest, residues (35.29\%), Collection of information from individuals and institutions (30.19\%), Scientific experiments and demonstrations (28.57\%), Visits to the farm $(21.31 \%)$, and Hunting and fishing (40\%). All these agro-ecosystem services are treated as public goods and their use and consumption are "managed" by providing free and unrestricted access by farm owners. Most of these services are difficult to regulate or exchange as private goods due to high uncertainty and enforcement costs.

In many cases the main form for providing access to the territory for the farm is Free but regulated - for Collection of unnecessary crops, residues (47.06\%), Visits to the farm $(72.13 \%)$, Collection of information from individuals and institutions (64.15\%), Scientific experiments and demonstrations $(64.28 \%)$ and Hunting and fishing $(60 \%)$. This form is widely used by a large number of farms in allowing access to the territory for Grazing animals of individuals and other farms $(41.18 \%)$, Collection of wild plants and animals $(22.22 \%)$, Organization of private events $(28.57 \%)$, Organizing public events $(25 \%)$ and Passing through the farm $(25 \%)$. The use and consumption of this type of agro-ecosystem services are managed through a private form - regulation, and they are provided free of charge by farm owners. The form of free provision is determined either by the additional benefits received for the farmers (in case of grazing animals of individuals and other farms, collection of unnecessary crops, residues, collection of wild plants and animals, organization of private and public events, etc.), or from the high costs of enforcement - constant control, penalties, disputing through a third party, etc. (in Passing through the territory of the farm, Hunting and fishing, etc.). Here, regulation is needed to plan and coordinate external access and/or limit consumption to maintain a sustainable supply of agro-ecosystem services.

Figure-9. Type of external access to farm's territory for use of different ecosystem services in Bulgaria

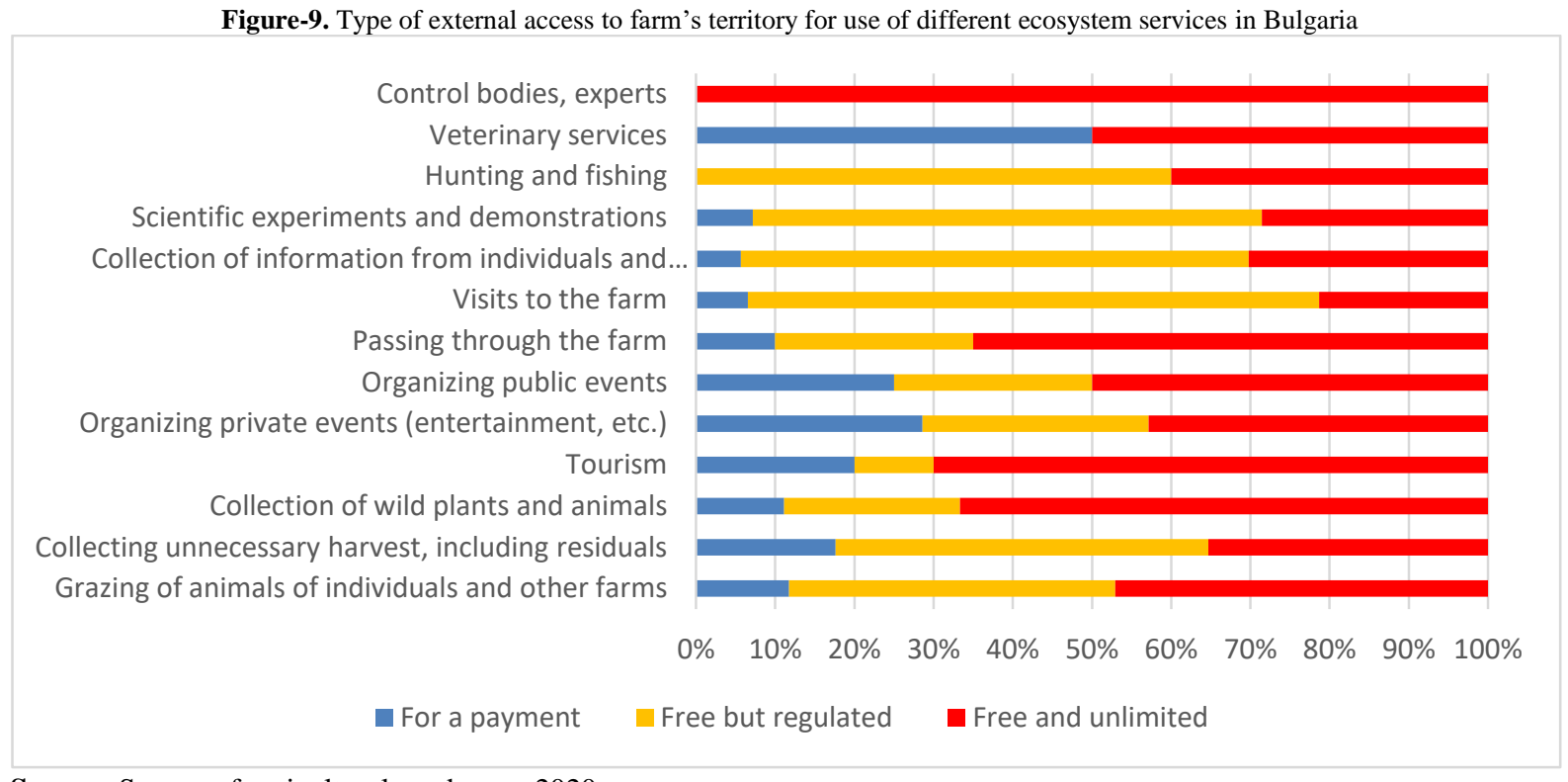

Source: Survey of agricultural producers, 2020

A portion of farms uses a market form of exchange against payment of a price to provide external access to the territory of the farms. This form of sale of services is practiced in grazing animals on individuals and other farms $(11.76 \%)$, collection of unnecessary crops, residues (17.65\%), collection of wild plants and animals $(11.11 \%)$, tourism $(20 \%)$, organizing private events $(28.57 \%)$, organizing public events $(25 \%)$, passing through the farm $(10 \%)$, visits to the farm $(6.56 \%)$, gathering information from individuals and institutions $(5.66 \%)$, scientific experiments and demonstrations $(7.14 \%)$ and veterinary Services $(50 \%)$. The market form is preferred because it governs well the supply of "limited" agro-ecosystem services and relationships of counterparts. Market trading is beneficial for both parties, who mutually profit from the transaction, as the terms of exchange are easy for no or lowcost negotiation, control and sanctioning. Here, the classic contract of "spotlike" exchange under standard conditions applies, and payment is made on the spot or in advance to avoid any possible opportunism.

Agricultural holdings with different specializations provide unequal external access on the territory to farms for using different agro-ecosystem services (Figure 10). To the greatest extent outside access to the territory of the farm for grazing animals of individuals and other farms is provided by holdings specialized in Grazing livestock (36.36\%) and Mixed crop-livestock operations (22.22\%). For Harvesting of unnecessary output, incl. Residues, most farms providing external access to their territory are among specialized in field crops $(21.43 \%)$ and crop-livestock $(14.81 \%)$. The largest share of mix crop-livestock farms $(11.11 \%)$ also allows the collection of wild plants and animals and tourism in their territory.

Specialized in grazing livestock to the greatest extent provide external access on the territory of their farms for Organizing private events (entertainment, etc.) (18.18\%) and Organizing public events (9.09\%). Most farms that allow passage through the farm territory are among those specialized in permanent crops (19.30\%) and grazing animals $(18.18 \%)$. Most visits to the farm are allowed by farms specializing in grazing animals $(63.64 \%)$ and field crops $(50 \%)$. The largest share of farms that allow the collection of information from individuals and institutions are 
among those specializing in permanent crops (43.86\%) and grazing animals (36.36\%), and for scientific experiments and demonstrations among those specializing in grazing animals $(27.27 \%)$ and Bee families (20\%). Every tenth farm with bee families also allows the use of its territory for hunting and fishing.

Therefore, in addition to the product specialization, there is a certain specialization in the provision of agroecosystem services related to external access on the territory of the farms.

Figure-10. Share of farms with a different specialization that provides external access to their territory for use of agro-ecosystem services in Bulgaria (percentages)

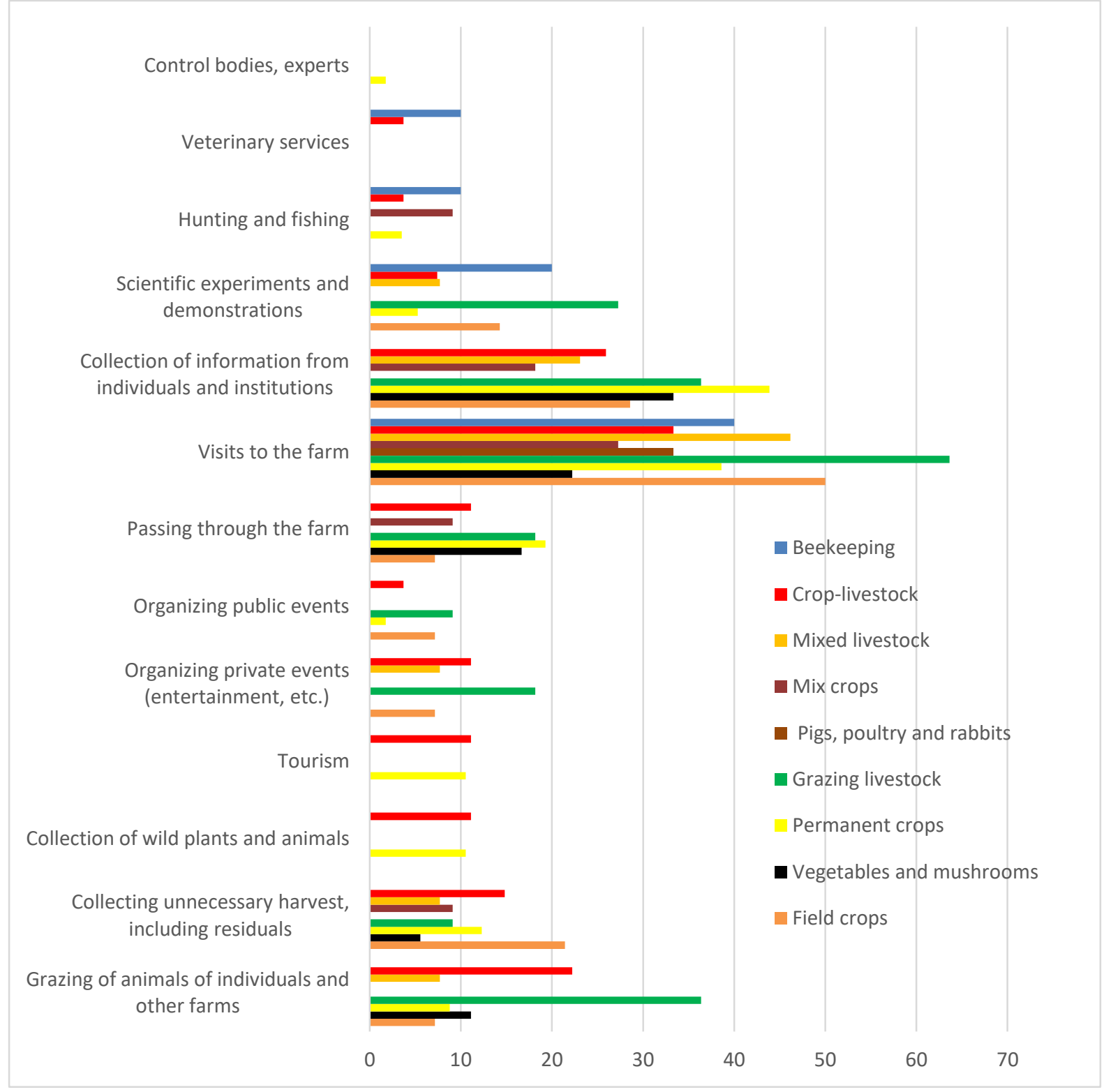

Source: Survey of agricultural producers, 2020

Farms with different specializations use unequally different forms for ensuring open access to the territory of farms for the use of agro-ecosystem services. The preferred most efficient mode is (pre)determined by the specifics of the production and the use of territory and/or the preferences of the owners/managers of the individual farms and the external users of the related agro-ecosystem services. For example, for farms specialized in field crops, vegetables and mushrooms, and mixed livestock, Free but regulated access is the only form used for providing external access to the territory for grazing animals to individuals and other farms. At the same time, most of the farms specializing in permanent crops practice Free and Unrestricted Access, while the remaining one-fifth apply for Paid access.

Similarly, relations with clients associated with Harvesting unnecessary output, incl. residues on the territory of farms specialized in Vegetables and Mushrooms, Grazing livestock and Mixed crops are managed entirely on a contractual basis for payment. At the same time, for all other groups of farms, the used form is either Free but regulated or Free and unrestricted access.

\section{Efficiency and Importance of Farms' Ecosystem Services Provision}

According to the majority of managers of the surveyed farms, their activity for the protection of ecosystems and their services is associated with an Increase in the total production costs of the farm, Increase of the specialized costs for nature protection, Increase of long-term investments, Increase of management costs and efforts, Growth of the 


\section{Sumerianz Journal of Economics and Finance}

costs of participation in state aid programs, Increase in the costs of studying the regulations and standards, and Increase in the costs of registrations, tests, certification, etc. (Figure 11). Moreover, for the majority of farms this activity leads to a high increase in the total production costs of the farm $(50 \%)$, the specialized costs for nature protection (40.58\%), long-term investments (50.7\%), the costs for participation in state aid programs (40\%), and the costs of registrations, tests, certification, etc. (50.75\%). At the same time, for only a small part of all farms, environmentally-friendly activity is associated with a reduction in the various types of production and transaction costs.

At the same time, however, the vast majority of farms report that their activities for the protection of ecosystems and their services are also associated with an Increasing the economic efficiency of the farm, Increasing the ecological efficiency of the farm, Increasing the social efficiency of the farm, Improved protection of ecosystems in the region, and Improved protection of ecosystems in the country. At the same time, the majority of farms estimate that their environmentally friendly activity leads to a high increase in the economic efficiency of the farm (59.09\%), the ecological efficiency of the farm $(55.22 \%)$ and the protection of ecosystems in the region $(47.54 \%)$.

None or very few of the surveyed farms indicate that their activities for the protection of ecosystems and their services are related to reducing the economic efficiency, environmental and social efficiency of the farm, and the protection of ecosystems in the region and the country. However, a significant share of farm managers believes that their efforts and costs to protect ecosystems and ecosystem services do not lead to changes in the social efficiency of the farm $(36.17 \%)$ and improved protection of ecosystems in the country $(37.78 \%)$.

Figure-11. Costs and efficiency of the activity of farms for protection of ecosystems and their services in Bulgaria (percentages)

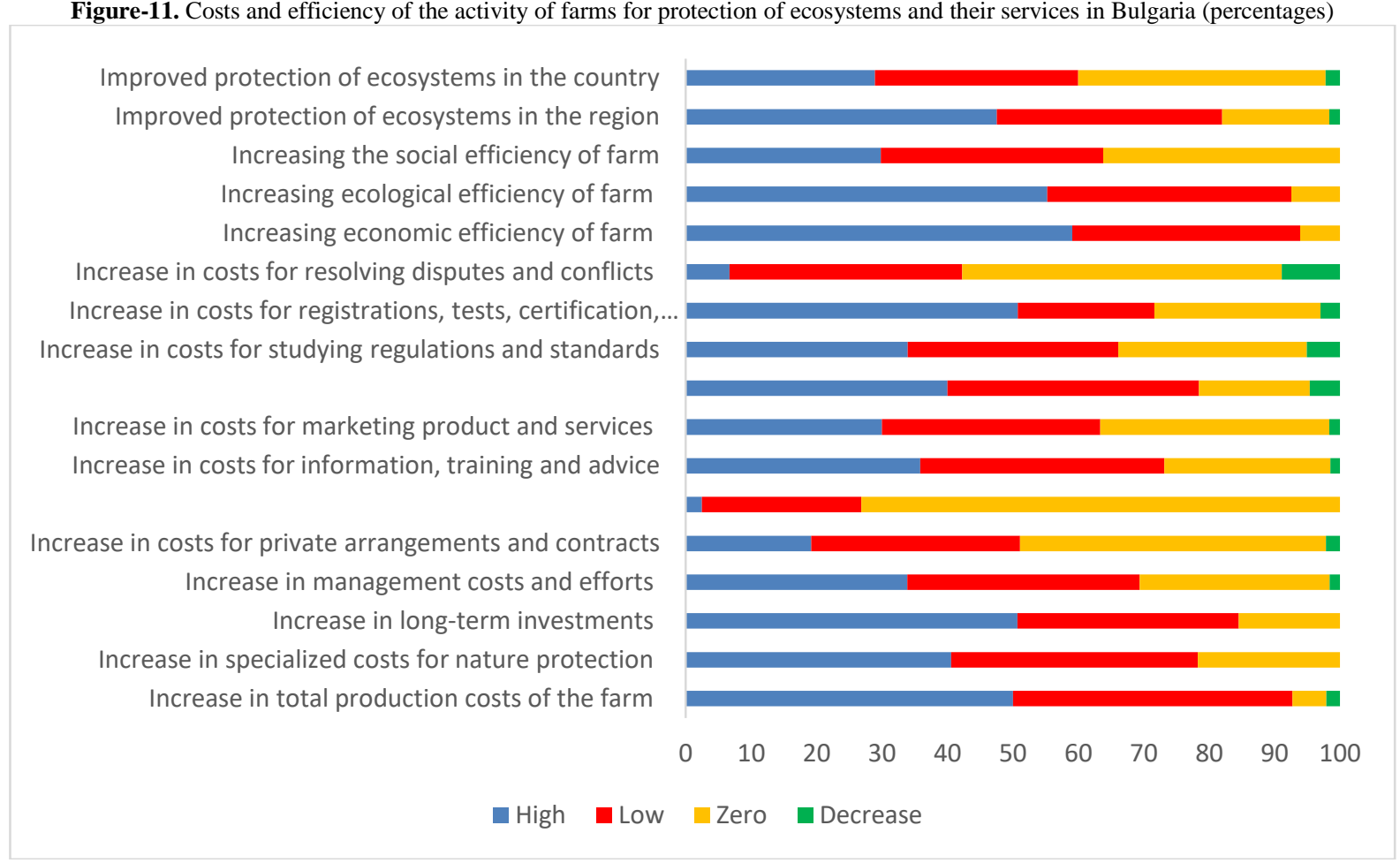

Source: Survey of agricultural producers, 2020

There is significant differentiation in the level of costs and efficiency of farm activities related to the protection of ecosystems and ecosystem services (Figure 12). A high increase in the total production costs of the farm was reported by half of the farms specializing in field crops and mixed crop production, three-quarters of those in grazing animals, and all of those in bee colonies. The share of farms with a high increase in these costs is the smallest among holdings specialized in vegetables and mushrooms (every third) and none in pigs, poultry and rabbits.

The largest share of farms with a high increase in specialized costs for nature protection are among those specialized in field crops, mixed crop production and crop and mix crop-livestock production (50\% each) and bee families $(100 \%)$. At the same time, relatively few mixed livestock farms (20\%) reported a high increase in this type of cost, and none among those specializing in grazing animals and pigs, poultry and rabbits.

A high Increase in long-term investments for the protection of ecosystems and ecosystem services is most typical for farms specializing in Vegetables and mushrooms (57.14\%), Herbivores (80\%), Mixed crop production (100\%), Crop and livestock production $(63.64 \%)$ and Bee families $(66.67 \%)$. The lowest share of farms with high costs of this type is in Permanent crops $(38.71 \%)$, and in none of the surveyed farms in Pigs, poultry and rabbits.

High increases in management costs and efforts to protect ecosystems and ecosystem services are recorded in most of the farms specializing in Vegetables and Mushrooms and Herbivores (every second of them) and Mixed crop production and Bee Families (all). At the same time, relatively few of the farms in Perennials $(21.4 \%)$ and Mixed Livestock (20\%), and none of those in Pigs, Poultry and Rabbits reported a high increase in these costs.

For a high increase in the costs of private arrangements and contracts related to the protection of ecosystems and ecosystem services, most farms report in Field Crops (40\%) and Bee Families (50\%), while in other groups a small number or none of the holdings have growth in these costs. A high increase in the costs of cooperation and 


\section{Sumerianz Journal of Economics and Finance}

association with others related to the protection of ecosystems and ecosystem services is observed in all farms specializing in beekeeping, while in other categories of farms this type of cost is not typical.

The most numerous are the farms with high Increase in costs for information, training and advice on ecosystem protection and ecosystem services in those specialized in Mixed Crop Production (100\%) and Bee Families (66.67\%), and relatively few in Field Crops (16.67 \%) and none for Grazing animals, and Pigs, poultry and rabbits. The largest share of farms with a high increase in the cost of marketing the product and services related to the protection of ecosystems and ecosystem services is in those specializing in grazing animals and mixed crop production (every second of them), bee families (all), relatively few in field crops (20\%) and perennials (16\%) and none among those in pigs, poultry and rabbits.

Figure-12. Share of farms with a high increase in costs and efficiency of activity for the protection of e cosystems and their services in Bulgaria (percentages)

\section{Beekeeping \\ crop-livestock \\ Mix livestock \\ Mix crops}

Pigs, poultry and rabbits

Grazing livestock

Permanent crops

Vegetables and mushrooms

Field crops
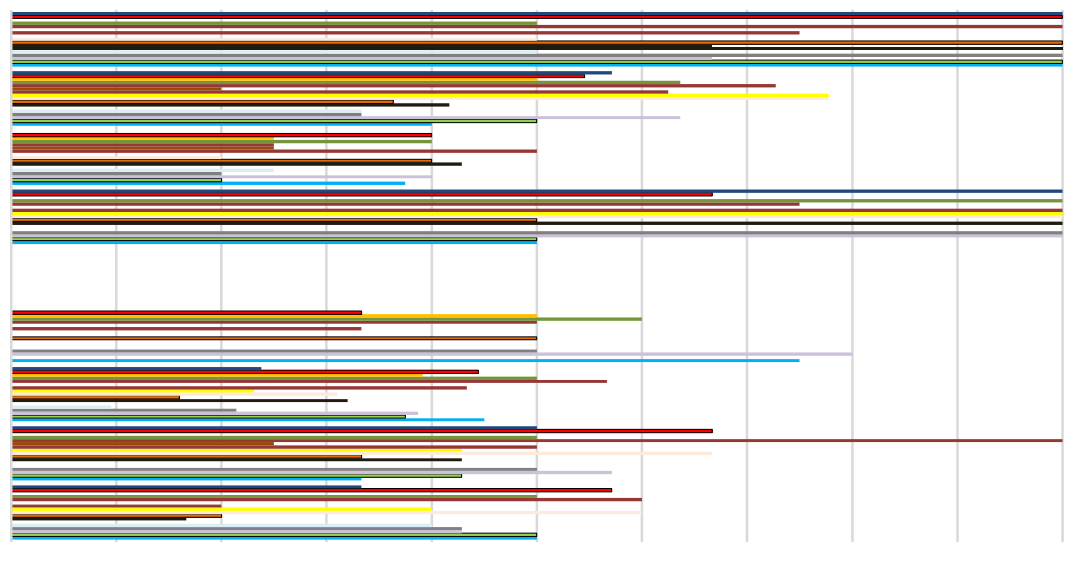
0
10
20
$40 \quad 50$
$60 \quad 70$

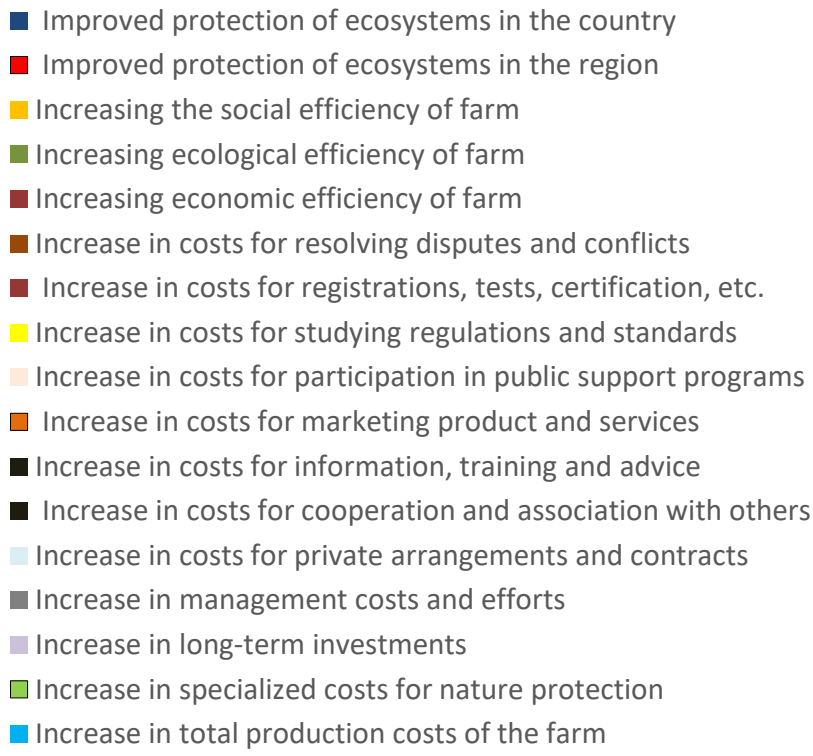

80

90

100

Source: Survey of agricultural producers, 2020

Most of the farms report high growth in the costs of participation in state aid programs related to the protection of ecosystems and ecosystem services, among those specialized in field crops $(60 \%)$, vegetables and mushrooms $(66.67 \%)$, mixed crop production $(100 \%)$, and mix crop-livestock $(77.78 \%)$. On the other hand, relatively fewer farms reported similar growth among specialized in perennials $(31.03 \%)$ and mixed livestock $(20 \%)$ and none of those with grazing animals and pigs, poultry and rabbits. The high growth of expenditures for studying regulations and standards related to the protection of ecosystems and ecosystem services was noted by the largest number of farms with Mixed crop produces (100\%) and Crop-livestock specialization (77.78\%). At the same time, a relatively small proportion of farms specializing in perennials (23.08\%) and none of those in grazing animals, pigs, poultry and rabbits, mixed livestock and bee colonies reported a similar increase in this type of expenditure.

The high growth of expenditures for registrations, tests, certification, etc. related to the protection of ecosystems and ecosystem services is observed in most farms with Mixed Crop Production (100\%), Crop-Livestock production $(62.5 \%)$ and Bee Families (75\%). This share is lowest on farms in field crops $(20 \%)$ and on none of those in pigs, poultry and rabbits. High growth in the costs of resolving disputes and conflicts related to the protection of 
ecosystems and ecosystem services is reported by every fourth farm specializing in Vegetables and Mushrooms and Mixed Livestock and every fifth of those in Bee colonies. However, none of the other holdings reported a similar increase in this type of expenditure.

High increase of the economic efficiency of the farm-related to the protection of ecosystems and ecosystem services is most noted in the farms specialized in Field crops (60\%), Vegetables and mushrooms (100\%), Mixed crop production (75\%), Mix crop-livestock production (72.73\%) and Bee families (100\%), and the least in those in Mixed livestock (25\%) and Pigs, poultry and rabbits (0).A high increase of the ecological efficiency of the holdings' activity for the protection of ecosystems and ecosystem services is reported by all from Mixed crops farms, and the majority of those with Grazing animals (60\%) and Crop and animal husbandry (63.64\%). The lowest share of farms with similar growth is in those specialized in Mixed Livestock (40\%) and Pigs, poultry and rabbits (0). High Increasing the social efficiency of the holdings' activity for the protection of ecosystems and ecosystem services is registered by every second farm specializing in Herbivores and Corp-livestock, a smaller part of those in Perennial crops $(39.13 \%)$ and Mixed livestock $(25 \%)$, and from none of the other categories of holdings.

High improved protection of ecosystems in the region, related to the activity of farms for protection of ecosystems and ecosystem services is achieved mostly by the farms in Field crops (57.14\%), Vegetables and mushrooms (66.67\%), Mixed crop growing (66.67\%), and Bee families (100\%), and relatively the least of those with Grazing animals $(33.33 \%)$ and Pigs, poultry and rabbits (0). High improved protection of ecosystems in the country related to the activities of farms for protection of ecosystems and ecosystem services is reported by all those specializing in Mixed crops and Bee families, and most of those in Mix crop-animal husbandry (57.14\%). The share of farms with a similar effect is the lowest in those specialized in field crops (33.33\%) and perennials (23.81\%), and in none of them in grazing animals, pigs, poultry and rabbits, and mixed animal husbandry.

The vast majority of farm managers estimate that the effect of the overall activity of the farm is positive in terms of soils (73.95\%), biodiversity (62.3\%), landscape $(51.11 \%)$ and economic development of the region $(60.82 \%)$ (Figure 13). Also, the majority of managers believe that the effect is positive in terms of Air (48.54\%), Surfacewaters $(36.2 \%)$, Groundwaters $(47.47 \%)$, Climate $(38.37 \%)$, Traditional breeds, varieties, products, technologies. (44.68\%), and Social development of the region $(48.89 \%)$, as a relatively smaller part consider a positive effect in terms of Local culture, traditions, customs, education (28.39\%). However, the share of managers who believe that the whole activity of their farm is not associated with any effect on the individual elements of the ecosystem - Soils (14.29\%), Air (29.13\%), Surfacewaters ( 34\%), Groundwaters (26.26\%), Biodiversity (16\%), Landscape (17.78\%), Climate (23.26\%), Traditional breeds, varieties, products, technologies (20.21\%), Local culture, traditions, customs, education (32.1\%), Economic development of the region (16.49\%) and Social development of the region $(18.89 \%)$.

Figure-13. Effect of farms' overall activity on different elements of ecosystems and their services in Bulgaria

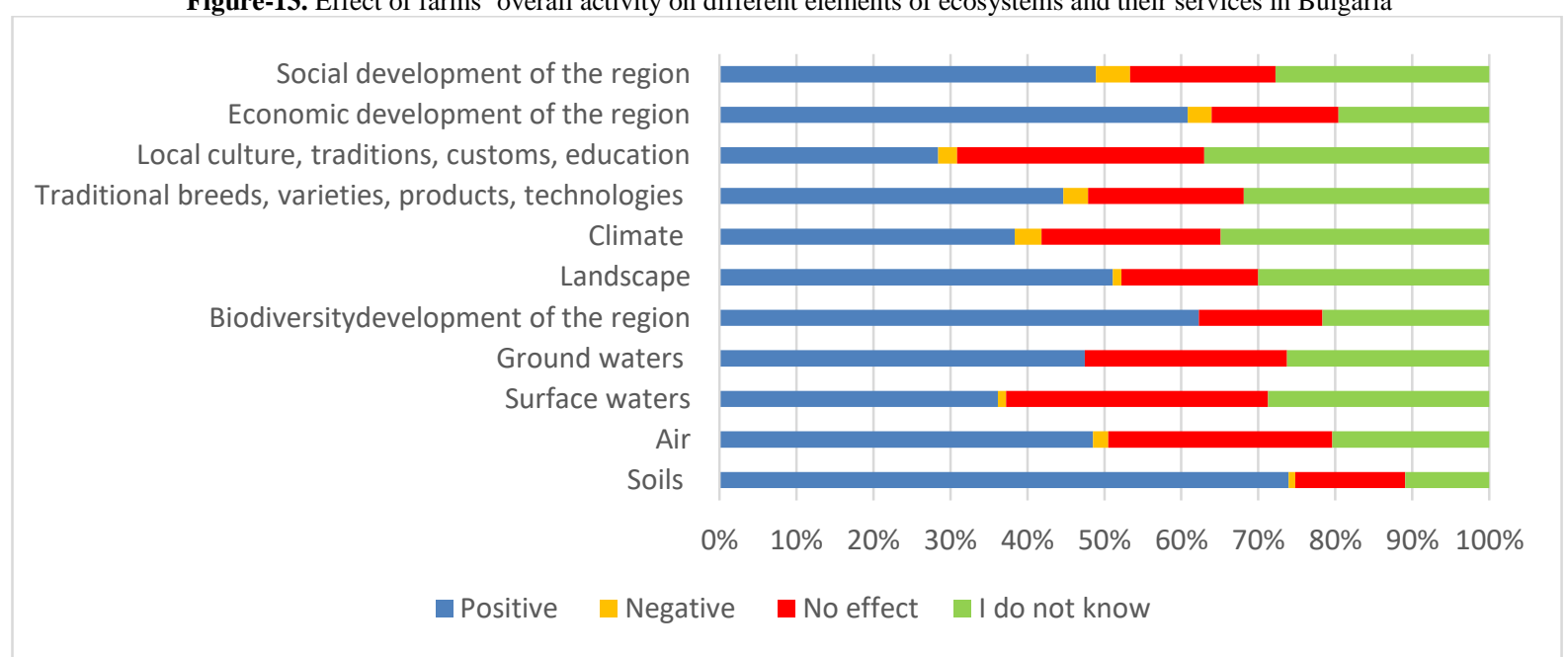

Source: Survey of agricultural producers, 2020

In addition, a significant part of managers do not know the effect of the overall activity of agriculture on various elements of the ecosystem - Soils (10.92\%), Air (20.39\%), Surfacewaters (28.7\%), Groundwaters (26.26\%), Biodiversity $(21.7 \%)$, Landscape (30\%), Climate (34.88\%), Traditional breeds, varieties, products, technologies $(31.91 \%)$, Local culture, traditions, customs, educated (37.04\%), Economic development of the region (19.59\%), and Social development of the region $(27.78 \%)$. The later requires both deepening and expanding independent assessments of the effects of farming on the individual components of ecosystems, and better informing farmers about their negative and /or positive contribution to environmental protection and ecosystem services.

Just over half of the surveyed managers assess the importance of their activities for the protection of agroecosystems and agro-ecosystem services as High for their farm $(50.62 \%)$ and $46.91 \%$ High for themselves (Figure 14). A significant share of managers also believes that their activities for the protection of agro-ecosystems and agroecosystem services are of high importance for the region of their farm $(27.16 \%)$. There is also a significant number of managers who believe that this activity has a high environmental value (14.81\%) and value for future generations $(13.58 \%)$. A relatively smaller part of the managers believes that such activity is of High importance for the community in the region (7.41\%), High market value (5.56\%) and High economic value (6.17\%). At the same time, 
an insignificant share of managers is convinced that their activity for the protection of agro-ecosystems and agroecosystem services has a High contract value (1.23\%), and a High social value $(2.47 \%)$ or is Without any value $(1.23 \%)$, as none of the respondents believes that this activity has a High cultural value.

Figure-14. Assessment of farm managers of the importance of their activity for the protection of agro-ecosystems and agro-ecosystem services in Bulgaria (percentages)

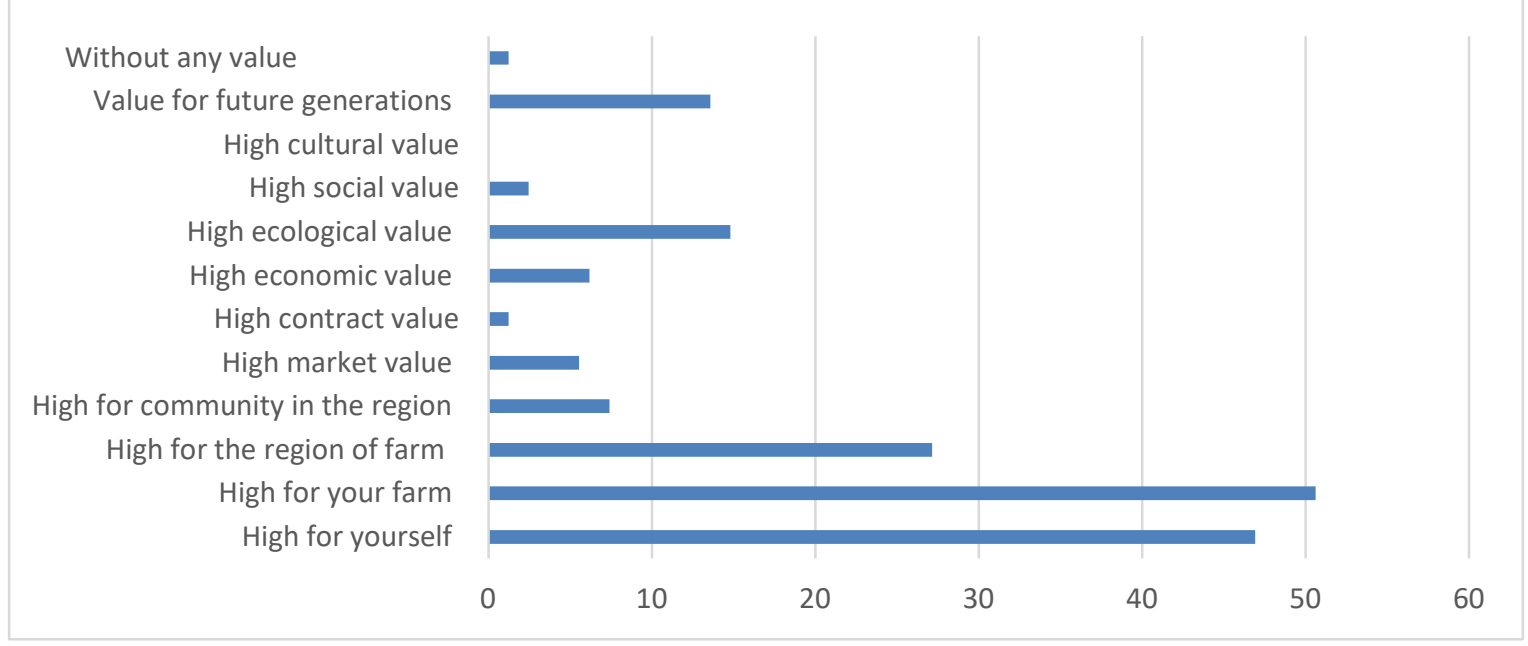

Source: Survey of agricultural producers, 2020

\section{Factors in the Governance of Agro-Ecosystem Services}

The survey allows us to identify personal, organizational, market, institutional and other factors that have the greatest impact on (and predetermine) the activity of agricultural holdings for the conservation of agro-ecosystems and agro-ecosystem services. According to the majority of surveyed managers, the factors that strongly stimulate or limit the activity of farms related to the preservation of agro-ecosystems are Market demand and prices (51.23\%), Market competition (37.65\%), Opportunities to increase profits (37.65\%), Participation in state and European support programs (37.04\%), Financial capabilities (35.8\%), Direct state and European subsidies received (34.57\%), Personal conviction and satisfaction with this activity (30.86\%), Amount of direct costs for this activity (29.63\%), Access to farmers' advice (24.69\%), Regulatory documents, standards, norms, etc. (24.69\%) and State Policy $(23.46 \%)$ (Figure 15).

The extent to which the activity for the protection of the agroecosystems of the affected farms is stimulated or limited by different factors is not the same. Factors that strongly stimulate the activity of the majority of agricultural producers for protection of agro-ecosystems and their services are: Market demand and prices (69.88\%), Market competition (57.38\%), Opportunities to increase profits (78.69\%), Initiatives and pressure of the public and interest groups $(61.11 \%)$, The presence of cooperation partners in this activity $(55 \%)$, Private contracts for the sale of related products and services $(65 \%)$, Initiatives of other farms $(68.18 \%)$, Immediate benefits for the farm in present and near future $(82.76 \%)$, Long-term benefits for the farm $(86.21 \%)$, Benefits for others $(75 \%)$, Integration with the supplier of the farm $(81.25 \%)$, Integration with the buyer of the production $(80.95 \%)$, Integration with processor $(80 \%)$, Available information and innovation (91.3\%), Proffesional training of managers and employees (91.67\%), Access to farmers' advices (92.5\%), Received direct state and European subsididies $(91.07 \%)$, Participation in state and European support programs $(95 \%)$, Tax preferences $(67.86 \%)$, Existence of a long-term contract with the state (68.42\%), Positive experience of other farms and organizations (87.5\%), Policies of the European Union (68.96\%), Public recognition of contribution $(60.87 \%)$, and Personal conviction and satisfaction with this activity $(88 \%)$ (Figure 16). 
Sumerianz Journal of Economics and Finance

Figure-15. Factors that strongly stimulate or restrict the activity of farms related to conservation of agroecosystems in Bulgaria (percentages)

Personal conviction and satisfaction from this activity Public recognition of your contribution European Union policies State policy

Environmental problems and risks in your region Environmental problems and risks on your farm Positive experience of other farms and organizations State control and sanctions for compliance with... Existence of long-term contract with the state Tax preferences Participation in state and European support programs Received direct state and European subsidies Official documents, standards, norms, etc. Access to farmers' advices Professional training of you and hired labor Available information and innovations Integration with processor of products Integration with buyer of products Integration with farm supplier Benefits received by others Benefits for you in the long run Immediate benefits for you now and near future Financial capabilities Initiatives of other farms Private contracts for sale of related products and... Presence of cooperation partners in this activity Initiatives and pressure from public and interest.. Cost-effectiveness of this activity

Amount of costs for information, training and Amount of costs for cooperation with other agents

Amount of direct costs for this activity Opportunities to increase profits Market competition Market demand and prices

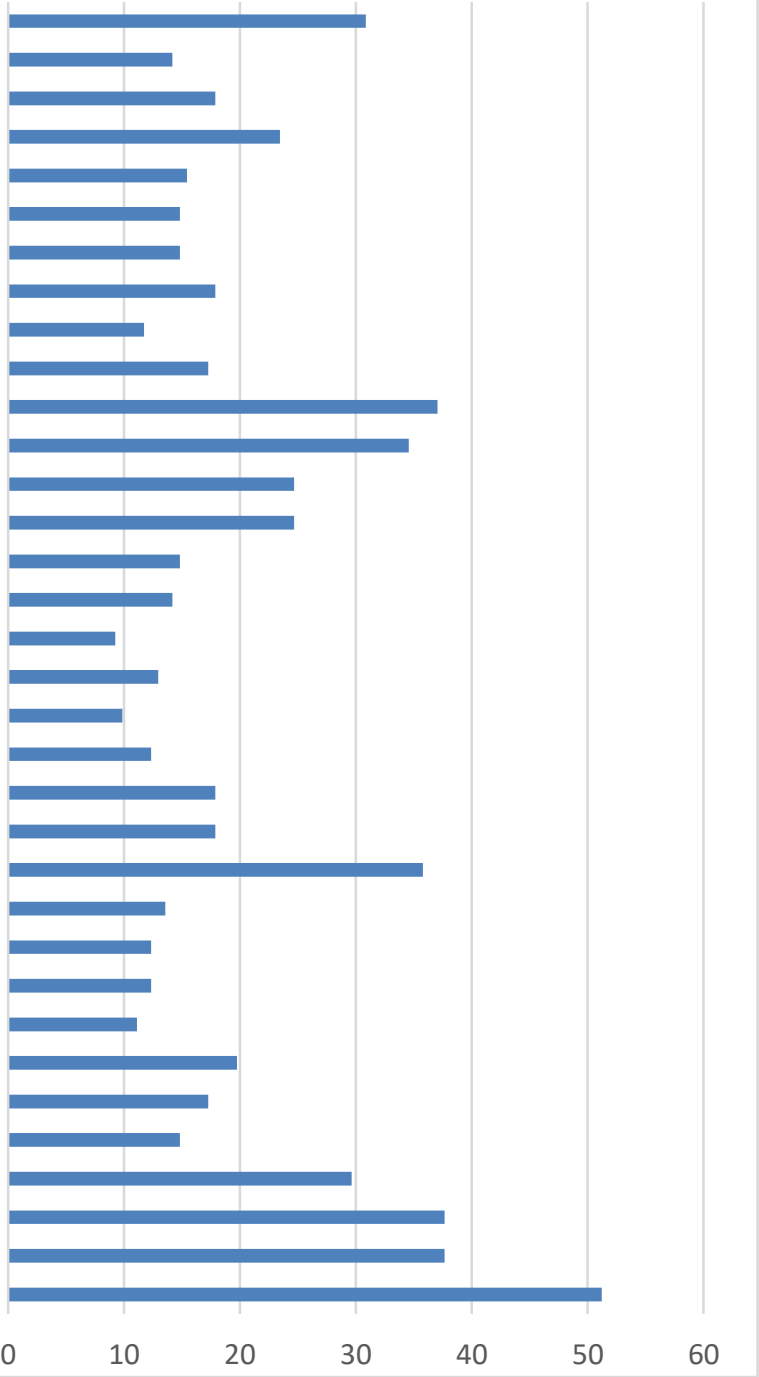

Source: Survey of agricultural producers, 2020

Factors that severely limit the activity of the majority of farms for the protection of agro-ecosystems and their services are the Amount of direct costs for this activity (70.83\%), the Amount of costs for cooperation with other agents (79.17\%), Economic efficiency of costs for this activity (62.5\%), Financial capabilities (58.62\%), Regulatory documents, standards, norms, etc. $(77.5 \%)$, State control and sanctions for compliance with standards, norms, etc. $(65.52 \%)$, Environmental problems and risks in the farm $(79.17 \%)$ and Environmental problems and risks in the region $(80 \%)$. At the same time, the Amount of information, training and consultation costs, and the State Policy are factors that strongly stimulate the environmentally friendly activity of half of the surveyed farms, and severely limit it for the other half. All these factors are to be taken into account when improving public policies and forms of intervention related to the governance of agro-ecosystems and their services. 


\section{Sumerianz Journal of Economics and Finance}

Figure-16. The extent to which farming activities related to the conservation of agroecosystems are stimulated or limited by various factors in Bulgaria (percentages)

Personal conviction and satisfaction from this activity Public recognition of your contribution European Union policies State policy Environmental problems and risks in your region Environmental problems and risks on your farm Positive experience of other farms and organizations

State control and sanctions for compliance with

Existence of long-term contract with the state

Tax preferences

Participation in state and European support programs Received direct state and European subsidies Official documents, standards, norms, etc. Access to farmers' advices Professional training of you and hired labor Available information and innovations Integration with processor of products Integration with buyer of products Integration with farm supplier Benefits received by others Benefits for you in the long run Immediate benefits for you now and near future

Financial capabilities Initiatives of other farms

Private contracts for sale of related products and.

Presence of cooperation partners in this activity Initiatives and pressure from public and interest groups

Cost-effectiveness of this activity

Amount of costs for information, training and Amount of costs for cooperation with other agents Amount of direct costs for this activity

Opportunities to increase profits Market competition Market demand and prices

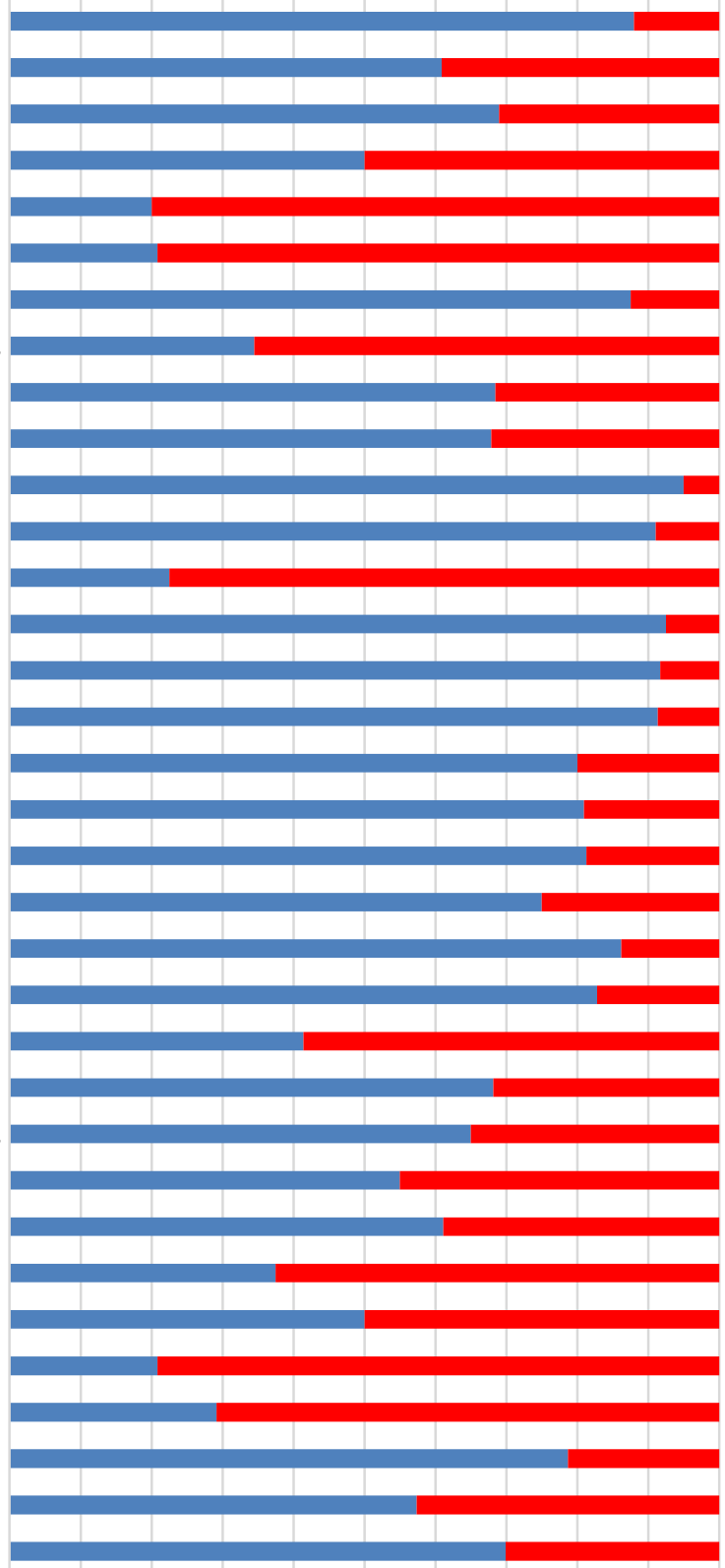

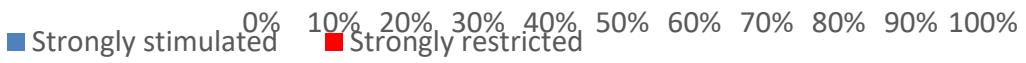

Source: Survey of agricultural producers, 2020

\section{Conclusion}

It is well known that agricultural production makes a significant contribution to the conservation, restoration and enhancement of ecosystems and their services, but also is associated with negative effect and their degradation and demolition (,,agricultural disservices“). Therefore, services related to agricultural production and agro-ecosystems are among the most intensively studied, mapped, evaluated, regulated and stimulated.

Our study has tried to fill the gap and give initial insighst on great variety of agricultural services and there importance for the farm, region, other ecosystems and agents in Bulgaria. At the current stage of development country's farms maintain or provide a great number of essential ecosystem services among which provisioning food and feed, and conservation of elements of the natural environment prevailing. Besides, there are significant differences in the participation and contribution of agricultural holdings in the protection and provision of agroecosystem services in the variouse specific and principled ecosystems of the country, and major subsectors of agricultural production. The later requires special measures to improve, diversify and intensify this activity of farmers through training, information, exchange of experience, public incentives and support, etc.

The study has also found out that there is significant differentiation of employed managerial forms depending on the type of ecosystem services and specialization of agricultural holdings. Management of agroecosystem services is associated with a considerable increase in the production and transaction costs of participating farms as well as big socio-economic and environmental effects for holdings and other parties. Factors that mostly stimulate the activity of Bulgarian producers for protection of agro-ecosystems and their services are participation in public support programs, access to farmers' advice, professional training, available information and innovation, received direct 
subsidies, personal conviction and satisfaction, positive experience of others, long-term and immediate benefits for the farm, and integration with suppliers, buyers and processors.

Suggested holistic and interdisciplinary framework for analyzing the structure and management of agroecosystem services is to be extended and improved, and widely and periodically applied in the future. The latter requires systematic in-depth multidisciplinary research in this new area, as well as collection of original micro and macro-information on structure of agro-ecosystes services, and forms, efficiency and factors of agroecosystem services management by agents involved in (joint) production and management of agro-ecosystem services of a different type. The accuracy of analyzes is to be also improved by increasing representativeness through enlarging the number of surveyed farms and related agents, applying statistical methods, special "training" of implementors and participants, etc. as well as improving the official system for collecting agricultural, agro-economic and agrienvironmental information in the country.

\section{References}

Adhikari, B. and Boag, G. (2013). Designing payments for ecosystem services schemes: some considerations. Current Opinion in Environmental Sustainability, 5(1): 72-77.

Allen, J., DuVander, J. Y., Kubiszewski, I. and Ostrom, E. (2011). Institutions for managing ecosystem services solutions. Solutions, 2(6): 44-49.

Bachev, H. (2009). Governing of agro-ecosystem services. Modes, efficiency, perspectives, VDM Verlag. Dr.Muller Aktiengesellscaft and Co. KG: Saarbrucken.

Bachev, H. (2010). Governance of agrarian sustainability. Nova Science Publishers: New York.

Bachev, H. (2011). Management of agro-ecosystem services: Framework of analysis, case of bulgaria, in j. Daniels (editor), advances in environmental research. 17 vols.: Nova Science: New York. 119-64.

Bachev, H. (2012). Governing of agro-ecosystem services in bulgaria, in a. Rezitis (editor), research topics in agricultural and applied economics. Bentham Science Publisher. 3: 94-129.

Bachev, H. (2018). The sustainability of farming enterprises in bulgaria. Cambridge Scholars Publishing.

Bachev, H. (2020a). Defining, analyzing and improving the governance of agroecosystem services. Economic Thought, 4: 31-55.

Bachev, H. (2020b). Understanding and improving the governance of ecosystem services: The case of agriculture. Journal of Economics Bibliography, 7(3): 170-95.

Bachev, H. (2021). Modes of governance for ecosystem services in bulgarian farms. Икономически изследвания, 8:

Boelee, E. (2013). Managing water and agroecosystems for food security. CABI.

De Groot, R., Wilson, M. and Boumans, R. (2002). A typology for the description, classification and valuation of ecosystem functions goods services. Ecol. Econ., 41(3): 393-408.

EEA (2015). Ecosystem services in the EU, european environment agency.

FAO (2016). Mainstreaming ecosystem services and biodiversity into agricultural production and management in East Africa, Technical guidance document. FAO.

Fremier, A., DeClerck, F., Bosque-Pérez, N., Carmona, N., Hill, R., Joyal, T., Keesecker, L., Klos, P., MartínezSalinas, A., Niemeyer, R., Sanfiorenzo, A., Welsh, K. and Wulfhorst, J. (2013). Understanding spatiotemporal lags in ecosystem services to improve incentives. BioScience, 63(6): 472-82.

Gao, H., Fu, T., Liu, J., Liang, H. and Han, L. (2018). Ecosystem services management based on differentiation and regionalization along vertical gradient, China. Sustainability, 10(4): 986.

Garbach, K., Milder, J., Montenegroand, M. and DeClerck, F. (2014). Biodiversity and ecosystem services in agroecosystems. Elsevier.

Gemmill-Herren, B. (2018). Pollination Services to Agriculture Sustaining and enhancing a key ecosystem service. Routledge.

Grigorova, Y. and Kazakova, Y. (2008). High nature value farmlands: Recognizing the importance of south east european landscapes, case study report, western stara planina, wwf (EFNCP).

Habib, T. S., Heckbert, J., Wilson, A., Vandenbroeck, J. and Farr, D. (2016). Impacts of land-use management on ecosystem services and biodiversity: an agent-based modelling approach. Peer J., 4: e2814. Available: DOI: $10.7717 /$ peerj. 2814

INRA (2017). A framework for assessing ecosystem services from human-impacted ecosystems. EFESE.

Kanianska, R. (2019). Agriculture and its impact on land-use, environment, and ecosystem services. INTECH.

Laurans, Y. and Mermet, L. (2014). Ecosystem services economic valuation, decision-support system or advocacy? Ecosystem Services, 7: 98-105. Available: https://doi.org/10.1016/j.ecoser.2013.10.002

Lescourret, F., Magda, D., Richard, G., Adam-Blondon, A., Bardy, M., Baudry, J., Doussan, I., Dumont, B., Lefèvre, F., Litrico, I., Martin-Clouaire, R., Montuelle, B., Pellerin, S., Plantegenest, M., Tancoigne, E., Thomas, A., Guyomard, H. and Soussana, J. (2015). A social-ecological approach to managing multiple agro-ecosystem services. Current Opinion in Environmental Sustainability, 14: 68-75. Available: https://www.sciencedirect.com/science/article/pii/S1877343515000391

Marta-Pedroso, C., Laporta, L., Gama, I. and Domingos, T. (2018). Economic valuation and mapping of Ecosystem Services in the context of protected area management. One Ecosystem, 3(1): e26722.

MEA (2005). Millennium ecosystem assessment, ecosystems and human well-being. Island Press: Washington, DC.

Munang, R., Thiaw, I., Alverson, K., Liu, J. and Han, Z. (2013). The role of ecosystem services in climate change adaptation and disaster risk reduction. Current Opinion in Environmental Sustainability, 5(1): 47-52. 
Novikova, A., Rocchi, L. and Vitunskienè, V. (2017). Assessing the benefit of the agroecosystem services: Lithuanian preferences using a latent class approach. Land Use Policy, 68: 277-86.

Nunes, P., Kumar, P. and Dedeurwaerdere, T. (2014 ). Handbook on the economics of ecosystem services and biodiversity. Edward Elgar: Cheltenham.

Petteri, V., D’Amato, D., Forsius, M., Angelstam, P., Baessler C., Balvanera, P., Boldgiv, B., Bourgeron, P., Dick, J., Kanka, R., Klotz, C., Maass, V., Melecis, V., Petrı,, P., Shibata, H., Tang, J., Thompson, J. and Zacharias, S. (2013). Using long-term ecosystem service and biodiversity data to study the impacts and adaptation options in response to climate change: insights from the global ILTER sites network. Current Opinion in Environmental Sustainability, 5: 53-66.

Power, A. (2010). Ecosystem services and agriculture: Tradeoffs and synergies. Philos. Trans. R. Soc. Lond. B Biol. Sci., 365: 2959-71.

Scholes, R., Reyers, B., Biggs, R., Spierenburg, M. and Duriappah, A. (2013). Multi-scale and cross-scale assessments of social-ecological systems and their ecosystem services. Current Opinion in Environmental Sustainability, 5(1): 16-25.

Todorova, K. (2017). Adoption of ecosystem-based measures in farmlands - new opportunities for flood risk management. Trakia Journal of Sciences, 15(1): 152-57.

Tsiafouli, M., Drakou, E., Orgiazzi, A., Hedlund, K. and Ritz, K. (2017). Optimizing the delivery of multiple ecosystem goods and services in agricultural systems. Frontiers in Ecology and Evolution, 5: 9715.

UN (2005). The millennium development goals report. United Nations: New York.

Van Oudenhoven, A. (2020). Quantifying the effects of management on ecosystem services: Available: https://www.wur.nl/en/show/Quantifying-the-effects-of-management-on-ecosystem-services.htm

Wang, S., Fu, B., Wei, Y. and Lyle, C. (2013). Ecosystem services management: an integrated approach. Current Opinion in Environmental Sustainability, 5(1): 11-15.

Williamson, O. (1996). The mechanisms of governance. Oxford University Press.

Wood, S., Karp, D., DeClerck, F., Kremen, C., Naeem, S. and Palm, C. (2015). Functional traits in agriculture: Agrobiodiversity and ecosystem services. Trends in Ecology and Evolution, 30(9): 531-39.

Zhan, J. (2015). Impacts of land-use change on ecosystem services. Springer.

Башев, X. (2012). Ефективност на фермите и аграрните организации. Икономическа мисъл, 6(4): 46-77.

Башев, Х. (2020). ДЕФИНИРАНЕ, АНАЛИЗИРАНЕ И УСЪВЬРШЕНСТВАНЕ НА УПРАВЛЕНИЕТО НА УСЛУГИТЕ НА АГРО-ЕКОСИТЕМИТЕ. Икономическа мисъл, 6(4): 3-30.

ИАОС (2020). Екосистеми и екосистемни услуги, Изпълнителната агенция по околна среда (ИАОС).

Казакова, Я. (2016). Земеделие с висока природна стойност (обучение, иновации, знания), УНСС.:

Недков, С. (2016). КОНЦЕПЦИЯ ЗА Екосистемни услуги, Презентация, работна среща 31 май 2016 г.

Николов, С. (2018). Екосистемни услуги и тяхното оценяване - кратък преглед. Journal of the Bulgarian Geographical Society, 39(51-54):

Тодорова, К. (2017). Управление на риска от наводнения чрез екосистемни услуги от земеделските стопанства, Дисертация, УНCC, WWF (2019): Екосистемите и техните „услуги”, WWF.

Чипев, Н., Св., Братанова -Дончева, К., Гочева, М., Жиянски, М., Мондешка, Я., Йорданов, И., Апостолова, Д., Сопотлиева, Н., Велев, Е., Рафаилова, Й., Узунов, В., Карамфилов, Р. and Фикова, С. В. (2017). Методологична рамка за оценка и картиране на състоянието на екосистемите и екосистемните услуги в българия ръководство за мониторинг на състоянието и развитието на екосистемите и екосистемните услуги, ИАОС. 